\title{
A Review of Procyanidin: Updates on Current Bioactivities and Potential Health Benefits
}

\author{
Razif Dasiman 1,5, * iD , Norazmir Md Nor 1 ${ }^{(D)}$, Zolkapli Eshak ${ }^{2,5}$ (D) , Siti Syairah Mohd Mutalip 2,5 (D), Nur \\ Rohmah Suwandi ${ }^{3}$ (D), Habsah Bidin 4 (D)
}

1 Faculty of Health Sciences, Universiti Teknologi MARA, Selangor Branch, Puncak Alam Campus, 42300 Bandar Puncak Alam, Selangor, Malaysia; razifdasiman@uitm.edu.my (R.D.), azmir2790@uitm.edu.my (N.N.);

2 Faculty of Pharmacy, Universiti Teknologi MARA, Selangor Branch, Puncak Alam Campus, 42300 Bandar Puncak Alam, Selangor, Malaysia; zolkapli_eshak@uitm.edu.my (Z.E.), syairah@uitm.edu.my (S.S.M.M.);

3 Faculty of Health Sciences, Universitas 'Aisyiyah Bandung, Jl. Banteng Dalam No.6, kel Turangga, Kec. Lengkong, Kota Bandung,40264 Jawa Barat, Indonesia; nur.rohmah@unisa-bandung.ac.id (N.R.S.);

4 Malaysian Agricultural Research and Development Institute (MARDI), Persiaran MARDI-UPM, 43400 Serdang, Selangor, Malaysia; habsahb@mardi.gov.my (H.B.);

5 Maternofetal and Embryo Research Group (MatE), Faculty of Medicine, Universiti Teknologi MARA, Selangor Branch, Sungai Buloh Campus, 47000 Sungai Buloh, Selangor, Malaysia; razifdasiman@uitm.edu.my (R.D.), zolkapli_eshak@uitm.edu.my (Z.E.), syairah@uitm.edu.my (S.S.M.M.);

* Correspondence: razifdasiman@uitm.edu.my (R.D.);

Scopus Author ID 55786067400

Received: 13.08.2021; Revised: 6.10.2021; Accepted: 9.10.2021; Published: 24.10.2021

Abstract: Procyanidin is an abundant polyphenol found in nature. It is composed of flavan-3-ol units, including catechin and epicatechin. Procyanidin is a polyphenolic polymer found in abundance in grapes, cranberries, apples, tea, cocoa, and pine bark. Procyanidin possessed antioxidant, anticancer, antitumor, anti-inflammatory, immunosuppressive, and antiallergy properties and protected against chronic diseases and metabolic disorders. Consequently, procyanidin may protect against chronic diseases such as cardiovascular disease, cancer, and immune-related diseases. Procyanidin acts as an anti-inflammatory, inhibits adipogenesis, melanogenesis, oxidative stress, and enhances lipid metabolism and macrophage activity. The current review summarized the numerous potential health benefits of procyanidin. Despite recent advances, multiple questions and challenges remain regarding procyanidin's action, biogenesis, and bioavailability mechanisms. Further investigation of procyanidin's metabolism, genetics, and cellular effects is necessary and should be pursued.

Keywords: procyanidin; polyphenol; bioactivity; diseases; health benefits.

(C) 2021 by the authors. This article is an open-access article distributed under the terms and conditions of the Creative Commons Attribution (CC BY) license (https://creativecommons.org/licenses/by/4.0/).

\section{Introduction}

Polyphenols are the most abundant secondary metabolites, and several of them have been discovered in plant-based food products [1]. Several studies have recently begun to report the various health benefits of consuming polyphenols like procyanidin that may reduce chronic diseases and metabolic disorders [2-4].

Procyanidin is gaining traction in the fields of nutrition and medicine. The number of studies on the potential health benefits of procyanidin has recently increased. Procyanidin is a naturally found polyphenol composed of flavan-3-ol units, epicatechins, and catechins [5-7]. It is a type of polyphenolic polymer that is widely distributed in grapes, grains, red wine, nuts, berries, apples, tea, cocoa, and pine bark [3, 5, 8-10]. Procyanidin can also be derived from flowers, leaves, and legumes [10-13]. 
This review will examine the occurrence and structure of procyanidin, bioavailability, antioxidant, anticancer, anti-inflammatory, antivirus, and immunosuppressive activity and a protective role against chronic diseases and metabolic disorders. In addition, some suggestions for studies involving procyanidin are discussed in this review.

\section{Occurrence, Chemical Structure, and Sources of Procyanidin}

Procyanidin is a proanthocyanidin composed of a homo-oligomeric structure (epi) catechin and two B-ring hydroxyl groups $[14,15]$. It is generally categorized as A-type or Btype based on the degree of polymerization and the stereo configuration between the monomers (Figure 1). An interflavan bond and a second ether linkage exist between the A-ring hydroxyl group and carbon-2 of the A-ring in A-type procyanidins. On the other hand, the B-type is distinguished by a single interflavan bond between carbon- 4 of the B-ring and either carbon- 8 or carbon-6 of the C-ring $[9,16]$. Oligoprocyanidins are procyanidins that contain 2-7 monomeric units. The most common monomeric unit is ()-epicatechin, with B-type being the most prominent, as reported by Tsao [1]. Procyanidin $\mathrm{C} 1$ is one of the B-type proanthocyanidins derived from (-)-epicatechin. It is made up of three (-)-epicatechin units linked together by two successive (4beta->8)-linkages. These units are typically connected by $\mathrm{CC}$ or C-O-C bonds (Figure 2). Procyanidin $\mathrm{C} 1$ is also widely recognized as cinnamtannin A1, proanthocyanidin $\mathrm{C} 1$, epicatechin, or procyanidol $\mathrm{C} 1[17,18]$.
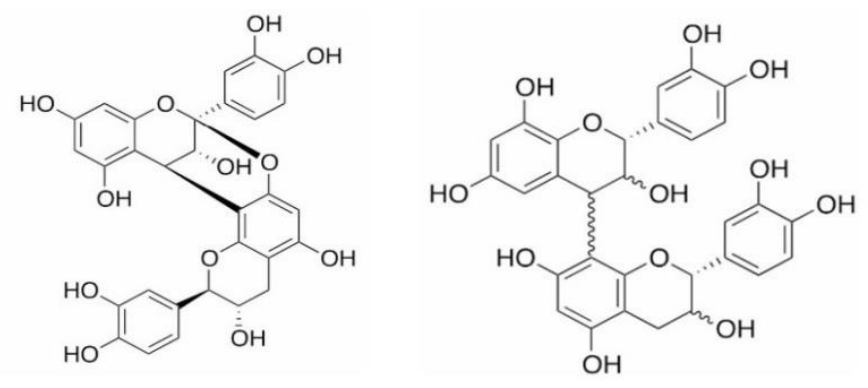

Figure 1. An A-type and a B-type of procyanidin structure.

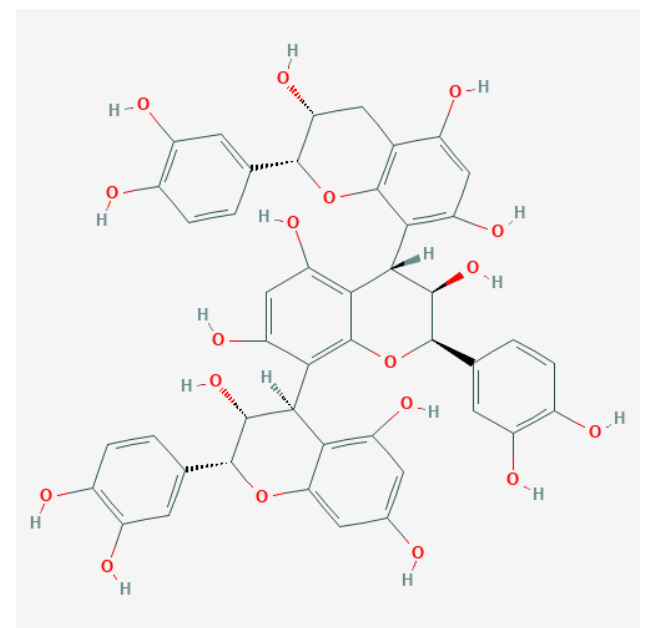

Figure 2. Molecular structure of Procyanidin C1 [18].

Procyanidin is widely distributed in legumes, fruits, grains, and leaves. Some of the foods that contain the highest concentration of procyanidin are chocolates [19, 20], apples $[6,21]$, and cocoa powder [22]. A lower concentration of procyanidin can be found in grapes $[4,8]$, red wine [23], kiwis $[24,25]$, and pears $[26,27]$. On top of that, procyanidin can be 
detected in flowers [11, 13], bananas [28, 29], lettuce [30, 31], legumes [12, 15], cinnamon [32], pumpkin [33] and tea leaves [11,34] (Figure 3).
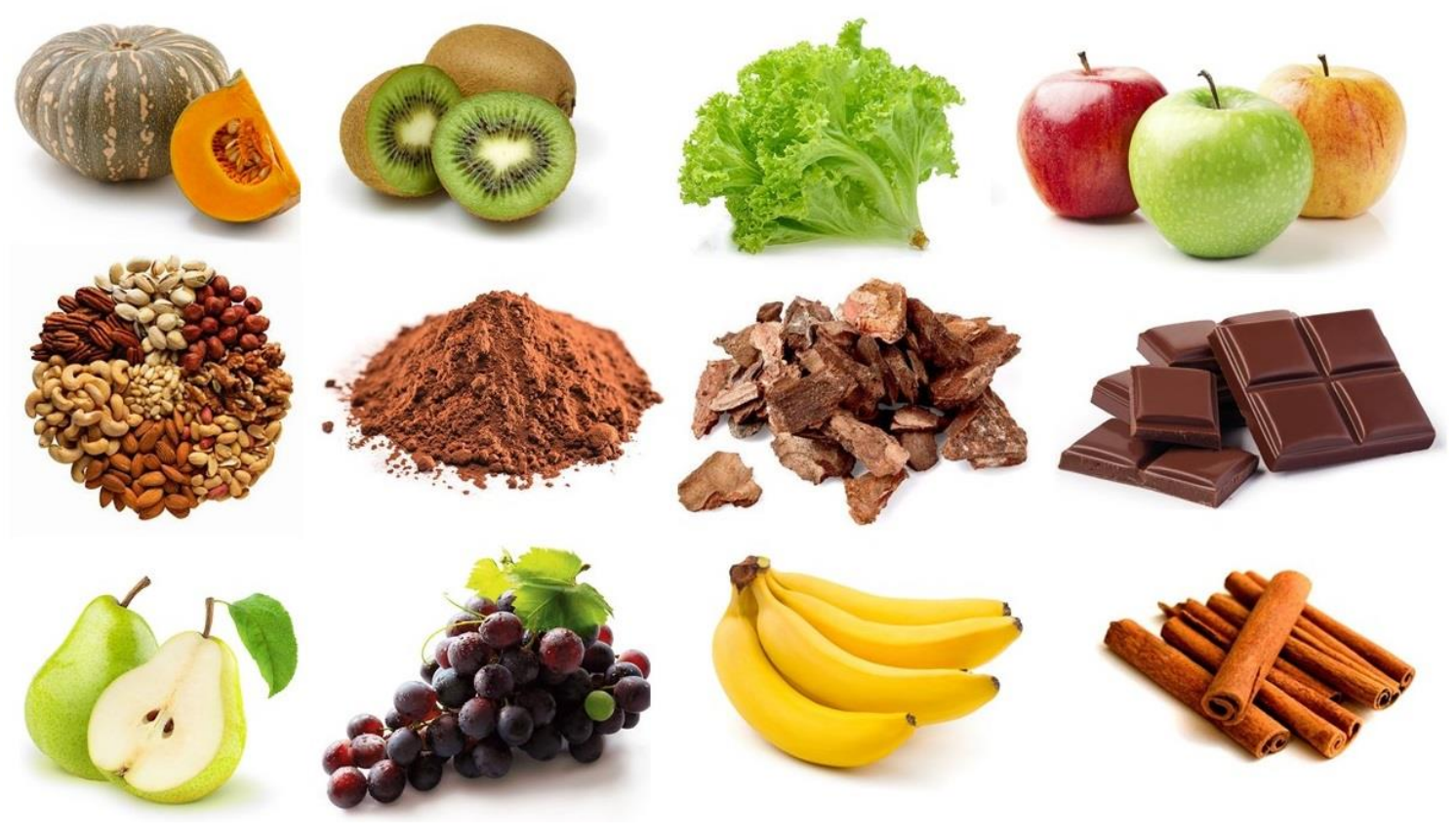

Figure 3. Various sources of procyanidin $\mathrm{C} 1$.

\section{Bioavailability and Metabolism}

Dietary polyphenols have recently attracted considerable attention among nutritionists and food scientists due to their abundance in almost all foods and possessed numerous health benefits. Several studies and models have been used to describe procyanidin absorption and bioavailability. In an in vitro study using human placental and rat liver models, the degree and position of methylation of procyanidin are dependent on the three-dimensional structure of the entire substrate molecule as reported by Weinert et al. They also discovered that human and rat cytosolic catechol-O-methyltransferase (COMT) methylated procyanidins and the trimer underwent monophasic, biphasic, or triphasic reactions, respectively [35].

Procyanidins are polyphenols with low oral bioavailability significantly affected by the type of food consumed. The absorption and bioavailability of procyanidins might be interrupted by carbohydrates, fibers, and protein. The interactions between these compounds may enhance the efficacy of the absorption process by causing synergistic or antagonistic effects [36-39]. The absorption process is highly dependent on the $\mathrm{pH}$ of the stomach's gastric juice. Other than that, procyanidin's molecular structure influences its bioavailability and function. Its absorption in the small intestine is indirect as it is determined by the type of monomer structure or dimer recognized by the plasma [40, 41]. Because of their smaller size, monomeric procyanidins are more absorbable than dimeric procyanidins. Large molecules are poorly absorbed through the intestinal barrier [40, 42, 43].

Procyanidins are extensively conjugated in the liver, accumulated in tissues, and excreted in the urine before returning to the intestine via bile. The gut microbiota will absorb and metabolize the depolymerized procyanidin before passing to the colon $[6,44,45]$. It is catabolized into low molecular weight phenolic acids in the colon [41, 46]. Procyanidin absorption is also closely related to the activity of gut microbiota in the intestine. This gut microbiota will degrade procyanidin molecules into other valuable metabolites in the intestines $[12,46]$. Additionally, consuming procyanidins boosts the intestinal flora of pig models, 
thereby improving physiological processes in the metabolism of carbohydrates, amino acids, energy, and nucleotides are recently reported by Zhao et al. [47]. Surprisingly, the phenolic acids degraded by the gut microbiota have a more significant biological effect than the original compound [45]. The procyanidins will also change the gut microbiota composition, acting as a natural treatment for diseases by increasing the positive biomarker and decreasing the bacteria ratio $[48,49]$.

\section{Antioxidant Activities}

Procyanidin has very potent antioxidant activity, which functions as a protective mechanism against oxidative stress caused by reactive oxygen species (ROS) in the environment $[5,22]$. Proanthocyanidins have 20 times the antioxidant capacity of vitamin $\mathrm{C}$ and 50 times the antioxidant capacity of vitamin E [50]. Aside from that, procyandin's antioxidant activity and scavenging capacity are proportional to its size and composition [25]. Its antioxidant function is frequently associated with reactive oxygen species (ROS).

ROS (reactive oxygen species) are produced by a variety of sources. They are divided into two categories: non-radical and free radical species. In general, ROS are formed from molecular oxygen via redox reactions or electronic excitation. Several processes in our body, such as differentiation, metabolism, proliferation, and apoptosis, are maintained in a normal physiological state by our body's endogenous antioxidative system. They keep the system in a state of dynamic redox equilibrium [51, 52]. Excessive production of reactive nitrogen species (RNS) and reactive oxygen species (ROS) causes oxidative stress (OS), and accumulation of ROS can trigger a cascade that causes direct damage to DNA, lipids, and proteins, ultimately leading to tissue dysfunction. Aside from that, ROS accumulation can contribute to the development of diseases, including cancers, neurodegenerative disorders, cardiovascular diseases, and metabolic disorders [32, 53, 54].

When the ROS level is low, it is usually advantageous and beneficial for cells and tissues, such as cell division, tissue repair, and angiogenesis. However, when the ROS level is high, and overproduction is hazardous because it causes apoptosis, cell damage, DNA mutations, and cell death [55-58]. Excessive ROS production disrupts multiple biomolecules, which can cause membrane damage. Furthermore, it will inactivate membrane receptors and enzymes, reduce membrane fluidity, increase membrane permeability to ions, and, in extreme cases, rupture the cell membrane and release organelles. In addition, lipid peroxides, nitric oxides, and superoxide radicals accumulate in cells and directly damage them by generating unstable radicals and interfering with natural antioxidant molecules and enzymes such as GSH, CAT, SOD, and GSH-Px [52, 59-63].

Procyanidin has been shown to prevent oxidative stress-induced DNA damage and promote DNA repair via various pathways. To progress, they disrupt oxidative stress damage and redox chain reactions by scavenging oxidative species like ROS and RNS. DNA repair enzymes, on the other hand, functioned better. The formation was then inhibited by the induction of IL-12, which promoted the nucleotide excision mechanism and inhibited DNA hypomethylation [64-67].

Studies on cultured cells and rat liver revealed that procyanidin supplementation could downregulate stress-activated MAPK and apoptosis-related pathways. Furthermore, they discovered that procyanidin could increase the expression and activity of antioxidant enzymes $[68,69]$. Another study on the lead-induced liver oxidative stress model discovered that 
procyanidin reduced oxidative stress by increasing Nrf2 gene expression and ARE-mediated transcription via Nrf2/ARE signaling pathway activation [62].

One of the primary functions of antioxidants is to prevent apoptosis and reduce the level of ROS in cells. A study showed that supplementing procyanidin reduced ROS production and inhibited apoptosis in oocytes. They also found that procyanidin increased mitochondrial membrane potential and glutathione levels, as well as oocyte quality and development [51]. Furthermore, other researchers discovered that procyanidin has an apoptosis-inducing effect on senescent cells under in vivo conditions in a study on human stromal cells. Procyanidins were also found to reduce senescence markers in solid organs and multiple tissues [54].

Researchers discovered that procyanidin supplementation significantly reduced UVBinduced lipid peroxidation $[63,70]$. It has been reported that combining procyanidin with DHA-OR improves PUFAs, reduces lipid hydroperoxides, and increases the detoxification of postprandial xenobiotics in rats [71]. Another study on rat erythrocytes and lymphocytes found that procyanidin supplementation could protect against cadmium-induced ROS production, free radical production, and lipid peroxidation [72].

Procyanidins inhibit lipases and cholesterol esterase in a dose-dependent manner. According to the findings, procyanidin fuses into insoluble complexes in the intestine, which reduces fat absorption, inhibits the formation of cholesterol micelles in the intestinal lumen, increases their fecal excretion, and thus reduces lipid digestion [3, 73]. In a liposomal membrane system, the procyanidin fraction exhibited higher antioxidant activity, influenced cell viability, and inhibited lipid peroxidation induced by 2,2'-azobis-2-methylpropanimidamide dihydrochloride $[74,75]$.

Procyanidin has been reported to inhibit inducible nitric oxide synthase-mediated nitric oxide production. Procyanidin was also found to influence the release of interleukin- 6 and tumor necrosis factor-, as well as the levels of prostaglandin E2 and cyclooxygenase-2, and the expression of cell surface molecules in lipopolysaccharide (LPS)-induced macrophages [76, 77].

\section{Anticancer and Antitumor Activity}

A redox imbalance in the body can cause disease to form. It is frequently associated with an increase or accumulation of oxidative stress. Oxidative stress can cause DNA mutations and epigenetic changes, as well as alter chromatin proteins. These conditions will cause disruptions in the normal functions of the cells and changes in the signaling pathways [52]. Cancer cells, in general, have an accelerated metabolism. A high level of ROS is needed to maintain their metabolic processes, progression, and proliferation. The presence of a high level of ROS will trigger and exasperate their metabolism, as well as vigorously assault and damage their DNA, lipids, and proteins [78-80].

Numerous studies on skin cancer and photoaging concluded that oxidative stress plays a role in developing and progressing skin cancer, chloasma, vitiligo, skin trauma, polymorphous light eruptions, psoriasis alopecia areata, dermatitis, and allergic purpura. Oxidative stress agitates dermatoses by causing DNA damage, interrupting lipids and proteins, and activating cytokine activities. Aside from that, oxidative stress activities impacted the preponderance of biochemical cascades, including Nrf2, MAPK, NF- $\mathrm{BB} / \mathrm{p} 65$, and PI3K/Akt [81-85]. 
Several in vivo and in vitro studies have shown that procyanidins can act as an anticancer agent by activating NF- $\mathrm{B}$, mitogen-activated protein kinases, PI3K/Akt, caspases, cytokines, angiogenesis, and cell cycle regulatory proteins [76, 86-88]. In the case of dermatoses, procyanidins act as antioxidants by repairing DNA damage, lipids, and proteins, according to Mantena et al. [89]. Procyanidin has been shown to control cytokine release, regulate oxidative stress-related signaling pathways, and induce oxidative stress-mediated dermatoses via the NF- $\kappa \mathrm{B}$ and MAPK pathways [89].

Procyanidins were discovered to have a chemopreventive effect on high-grade prostate cancer [90]. This study supported the findings from the discovery that a combination of procyanidin and its active constituent could target cancer stem cells in prostate cancer. Their findings revealed that procyanidin and its constituents significantly reduced the constitutive (Notch1 ligand)-induced activated Notch1 pathway targeting prostate cancer growth and tumor relapse [91].

Furthermore, procyanidins have been shown to prohibit the progression and proliferation of xenograft tumor growth, as reported by Ravindranathan and colleagues [92]. They discovered that procyanidins significantly inhibit the formation of colorectal cancer patient-derived organoids in vivo experimental models. The study was then confirmed in cancer cell lines and mouse xenografts using cell cycle and DNA replication-associated genes analysis. Procyanidins have anticancer properties in colorectal cancer, according to their evidence. Another study on lowbush berry procyanidins found that they induce apoptosis in human colorectal cancer cell lines [93].

Procyanidin was discovered to inhibit human colorectal adenocarcinoma (Caco-2) cells in another study. Researchers found that procyanidin with low molecular weight enhanced fluoropyrimidine 5-fluorouracil (5-FU) in cancer treatment. The bioactivity also outperformed the standard 5-FU chemotherapy anticancer agent [94]. Procyanidins were also used to treat colorectal cancer (CRC) cells in another study. The findings demonstrated that procyanidin could impede CRC cell growth via the Akt kinase pathway, which explains the potential of a procyanidin-rich ability to reduce the risk of developing colorectal cancer [95].

Apart from that, procyanidins extracted from grape seeds were demonstrated to inhibit and down-regulate COX-2/PGE2 pathways in lung cancer. And apart from that, there was a significant increase in PGI2 and 15-HETE against lung cancer. Procyanidin extracted from grape seeds also targets IGFBP-3 enzymes in lung cancer related to the IGF-I/IGF-I receptor/IGFBP-3/phosphatidylinositol 3-kinase pathway [96]. Procyanidin has antiproliferative, apoptotic, and autophagic effects on gastric cancer cells by modulating the Akt/mTOR signaling pathway [97].

Furthermore, procyanidins from Lafoensia pacari are cytotoxic to lung cancer cells by inducing caspase-3-dependent apoptosis. Caspase-3 activation triggered sub-G1 cell cycle arrest in cancer cells, implying cell death [98]. In another study on B-cell lymphoma cancer, researchers found that procyanidins inhibited cell migration and invasion at the G2/M phase. This study's results also revealed a significant decrease in the levels of interleukin (IL)-6, IL1 , and tumor necrosis factor (TNF) [99].

Procyanidin was also used to treat another type of cancer cell, the human breast cancer cell line (MCF-7). According to the study's findings, procyanidin significantly inhibited MCF7 cell proliferation in a concentration/time-dependent manner. They also discovered that procyanidin induced cell cycle arrest and apoptosis by suppressing the EGFR/VEGF/MMP9 pathway [100]. Vorinostat treatment is always used in the treatment of non-small cell lung 
cancer (NSCLC). NCSLC causes the majority of lung cancer cases. The study discovered that combining vorinostat and procyanidin had a synergistic anti-proliferative effect and increased apoptotic cell death. As a result, it was proposed as an effective antitumor therapy for the treatment of NSCLC [101].

Procyanidins were also tested on human bladder cancer (BIU87) cells and analyzed using a semi-quantitated RT-PCR and Western blotting, as demonstrated by Liu and colleagues [102]. They discovered that procyanidin treatments impaired cell proliferation by arresting the cell cycle at the G1 phase and induced apoptosis by increasing the level of caspase-3. Other researchers investigated the effect of procyanidins from apples on oesophageal adenocarcinoma (OA) cells. They found that procyanidins reduced cell viability, induced apoptosis, and caused cell cycle arrest in G0/G1. These findings suggest that procyanidins derived from apples could have chemotherapeutic effects on OA cells [103].

\section{Anti-Inflammatory Activity}

Procyanidins' anti-inflammatory activity was also investigated using various models. For example, ultraviolet radiation induces erythema, edema, and hyperplastic epithelial responses, all of which play important roles in forming skin tumors. The research found that dietary intake of procyanidins influences cyclooxygenase-2 (COX-2) enzyme expression, inhibits UV radiation-induced edema, erythema, infiltration of inflammatory leukocytes, and myeloperoxidase activity in mouse skin [65, 104].

In another study, researchers discovered that the transcription of the transcription factor $\mathrm{NF}-\kappa \mathrm{B}$ was directly linked to regulating genes involved in oxidative stress, apoptosis, and inflammation. NF- $\kappa \mathrm{B}$ proteins are normally retained in the cytoplasm alongside $\mathrm{NF}-\kappa \mathrm{B}$ inhibitory proteins. Multiple cellular stressors, such as oxidants, antigens, and oxidative stress, will trigger and activate it. All cellular stressors will elicit phosphorylation, which will detach the protein from NF- $\kappa \mathrm{B}$ before it is degraded, allowing NF- $\kappa \mathrm{B}$ translocation into the nucleus. Procyanidin treatment was proven to affect oxidative damage and inflammation by influencing the suppression of NF- $\mathrm{kB}$, ERK, p38, and JNK phosphorylation. Procyanidins inhibited the $\mathrm{NF}-\kappa \mathrm{B}$ and MAPK pathways, which hindered the mRNA expression of proinflammatory cytokines and COX-2 inflammatory prostaglandin products [87, 105-107].

Another discovery found that procyanidins inhibit the LPS-induced production of reactive oxygen species (ROS), and the anti-inflammatory activities were triggered by the inhibition of the ERK1/2 and IKKb enzymes. The research also discovered that procyanidins impeded IKKb activity in vitro [88]. Furthermore, procyanidins derived from red rice negatively impacted interleukin-6, tumor necrosis factor-, and nitric oxide production in LPSinduced Raw 264.7 cells. Aside from that, the findings revealed that procyanidins inhibit the phosphorylation of extracellular signaling-regulated kinases and p38 MAPK signaling, which are responsible for the expression of inflammatory mediators in LPS-stimulated Raw 264.7 cells [106].

Furthermore, supplementing procyanidins from grape seeds reduced the release of inflammatory cytokines IL-6 and TNF-, increased the activity of Nrf2, superoxide dismutase, and catalase, and significantly reduced the output of malondialdehyde and hydrogen peroxide in PFOA-treated mice. The findings also showed that procyanidin supplementation tends to increase the expression of the anti-apoptotic protein Bcl-2 while decreasing the expression of the pro-apoptotic proteins p53 and Bax, as well as the activity of caspase- 3 in the liver. They 
suggest that procyanidins reduce PFOA-induced inflammatory response, oxidative stress, and apoptosis in the mouse liver [108].

In the classic knockout model that develops spontaneous colitis, supplementation of procyanidins derived from grape seeds indicated that supplementing colitis animals with various concentrations of procyanidins for 12-16 days significantly decreased the expression of multiple inflammatory markers, which was associated with the suppression of NF- $\mathrm{BB}$ signaling in the colitis animals. The findings also reveal the effect of procyanidins on the density of goblet cells in the jejunum of treated animals, implying that the inflammation process was slowed by another mechanism in the treated animals [109].

In other studies, researchers discovered that procyanidin $\mathrm{C} 1$ promotes antiinflammatory activity in macrophages. They discovered that procyanidin treatment reduced prostaglandin E2 and cyclooxygenase-2 levels and the expression of cell surface molecules like CD80, CD86, and MHC class II. The findings also revealed that procyanidins have an antiinflammatory effect by inhibiting the mitogen-activated protein kinase and nuclear factor-B signaling pathways $[76,110]$.

\section{Immunosuppressive Properties and Anti-Allergy}

Procyanidins have also been shown in numerous studies to have immunosuppressive and antiallergy properties. Various disorders, such as systemic lupus erythematosus, uremia, Behcet's disease, and irritable bowel disease, may also involve molecules and pathways targeted by procyanidins. Caspases, PERK/NRF2, NADPH oxidase, and JNK/MAPK signaling cascades are part of the pathway [52]. As a result, the impact of procyanidins on disease prevention is the most plausible in ameliorating various immune disorders. Despite many in vitro and cell-based evidence of immunomodulatory effects, animal model studies are limited; therefore clinical evidence is urgently required before granting credible dietary or supplement recommendations and complementary treatments based on procyanidins [34].

Other researchers reported interesting clinical evidence for lupus nephritis prevention. The researchers discovered that procyanidin suppresses inflammation and significantly affects NLRP3 inflammasome activation, and lowers renal and serum levels of IL-1b and IL-18 in MRL/lpr mice [111]. Another study reported that procyanidin C1 trimer is a promising metabolite for the reactivation of latent HIV-1 reservoirs. They discovered that NF-kBdependent transcription peaked 12 hours after stimulation and then declined significantly, implying Tat-mediated self-sustainability of HIV-1 expression [17].

Procyanidin oligomers from cinnamon bark possess immunosuppressive properties and could be used to treat immune-related diseases [112]. They discovered that the oligomers significantly suppressed splenocyte proliferation and decreased interferon and interleukin-2 levels. In another study, researchers used procyanidins derived from grape seeds to treat UVBexposed mice. Procyanidins inhibit UVB-induced immunosuppression by stimulating CD8 effector T cells and decreasing regulatory CD4 T cells, according to the study's findings [67]. In UVB-exposed mice, procyanidins from grape seed extracts also demonstrated immunosuppressive activity by inducing regulatory $\mathrm{T}$ cells (Treg cells), inhibiting photocarcinogenesis, and promoting DNA repair in dendritic cells [67, 113].

In a mouse model of experimental autoimmune encephalomyelitis, highly polymerized procyanidins from Jatoba extracts were injected (EAE). The researchers reported a decrease in both dendritic and CD4-T cells in this study. They also reported the inhibition of CD80 and 
MHC class II molecule expression, indicating immature macrophages and reducing antigenpresenting capability [114]. Recent psoriasis research demonstrated that procyanidins are an excellent candidate for psoriasis management and can be used in conjunction with other substances, such as anti-cytokine biologics. They discovered that procyanidins could induce the proliferation and differentiation of Th17/Th1/Th22 cells while also impairing the antiinflammatory activities of regulatory $\mathrm{T}$ lymphocytes [115]. Furthermore, a study found that procyanidins impeded morphine-induced increases in interleukin-1 and activation of the NODlike receptor protein3 (NLRP3) inflammasome, suppressing nuclear factor-B translocation curtailed the level of reactive oxygen species in microglia in a study of procyanidins and morphine co-administration [116].

\section{Improves Reproductive Parameters and Fertility}

It has been demonstrated that procyanidins affect reproductive parameters, development, and fetal health. However, additional research is urgently needed to understand their potential benefits for health, physiology, mechanisms, and clinical utility concerning reproduction and fertility. This section will summarize the research on the effects of procyanidins on reproductive parameters, development, and fetal health.

Researchers conducted a cross-sectional before-and-after study on twenty-nine patients with idiopathic male infertility (IMI) to determine the effect of procyanidin on seminal parameters. They determined the levels of seminal catalase, superoxide dismutase, malondialdehyde, and serum FSH, LH, and testosterone at the start and end of the study. Their findings indicated that procyanidin treatment alleviated seminal oxidative stress in patients with IMI by increasing semen catalase, decreasing semen malondialdehyde, and increasing serum FSH levels [117].

The effect of procyanidins on reproductive parameters and fertility has been studied using a variety of animal models. Procyanidin treatment improved sperm motility in Merino rams during the non-breeding season, according to a study [118]. Furthermore, procyanidin was tested on black boar sperm to evaluate the quality of the sperm during liquid preservation at $17^{\circ} \mathrm{C}$. When compared to the control group, procyanidin improved boar sperm motility, acrosome integrity, membrane integrity, and mitochondrial membrane potential [119].

In another study, procyanidin derived from grape seeds was used to treat goat sperm. The researchers discovered that the treatment groups had significantly higher sperm motility, acrosome membrane integrity, mitochondrial activity, plasma membrane integrity, total antioxidant capacity, catalase activity, and superoxide dismutase activity than the control group, while the control group had significantly lower malondialdehyde (MDA) content. Additionally, they discovered that litter sizes were larger in the procyanidin-treated group than in the control group following artificial insemination (AI) [120].

The effect of procyanidin supplementation was also examined on porcine oocytes' in vitro maturation (IVM). The findings indicated that supplementation with procyanidin reduced ROS production and apoptotic levels. Additionally, procyanidin has been shown to increase both mitochondrial membrane potential and glutathione (GSH) levels. Thus, they concluded that procyanidin enhanced the quality of oocytes and stimulated embryonic development [51].

Additionally, procyanidin was studied in rabbits to determine some male reproductive parameters. A study demonstrated that procyanidin derived from a methanolic extract of Phoenix dactylifera dramatically reversed the detrimental reproductive effects of Cadmium 
(Cd) by increasing semen quality, motility, libido, semen concentration, total ejaculation, viability, and morphology. Additionally, they discovered that the control rabbits' testis density and epididymis length were significantly different from those of the Cd-only exposed rabbits [121]. The study was confirmed by other researchers that revealed the protective effect of procyanidins against cadmium $(\mathrm{Cd})$-induced testicular apoptosis, inflammation, and oxidative stress in rats. They discovered that procyanidin protected DNA from damage and increased the expression of antioxidant responsive elements Nrf2/HO-1 in cadmium (Cd)-induced rats via a PI3K/Akt-dependent pathway [72].

Aluminum chloride $\left(\mathrm{AlCl}_{3}\right)$ has been shown to significantly impair reproductive quality, increase oxidative stress, and alter the testicular structure and hormonal levels. A study demonstrated that procyanidin treatment improves the histological structure of the testis and greatly enhances the damaged tissue in $\mathrm{AlCl} 3$-induced rats [122]. Procyanidin administration also resulted in a significant decrease in spermatogenic cell apoptosis, an increase in serum testosterone levels, sperm quality, and histological characteristics of the testicular tissue, as well as a significant increase in antioxidant enzyme activities (SOD, GSH, and GSH-Px) and a remarkable decrease in MDA. This study demonstrated that procyanidin inhibited testicular dysfunction and possessed anti-apoptotic activity in rats fed a high-fat diet (HFD) [123]. Additionally, procyanidins enhance sperm motility by inhibiting the c-kit expression and reversing the apoptosis and oxidative stress induced by nickel (Ni) through directly lowering MDA and $\mathrm{NO}$, scavenging $\mathrm{H}_{2} \mathrm{O}_{2}$, and downregulating Bax expression [124].

In another study of HFD-induced rats, the offspring of rats fed an HFD and treated with procyanidin had a significantly higher adiposity index and weight of all-white adipose tissue (retroperitoneal, mesenteric, epididymal, and inguinal) than the offspring of rats fed an HFD but not treated with procyanidin. The procyanidin-treated group had more epididymal cells, lower circulating levels of MCP-1, and lower plasma glycerol levels. They suggested that procyanidin treatment in pregnant and lactating rats increased adiposity, decreased MCP-1 circulating levels, and altered gene expression associated with immune function and inflammatory response [125]. All biochemical parameters, including total lipids, total cholesterol, triglycerides, phospholipids, and low-density lipoprotein cholesterol, were recovered in the serum and histological testicular disorders of procyanidin-supplemented rats, indicating procyanidin's protective effect [126].

The detrimental effects of bisphenol A (BPA) on subsequent generations were also investigated using procyanidin from grape seeds, as recently reported by Zulazlan and colleagues' [127]. Their findings through oligonucleotide array-based comparative genomic hybridization $(\mathrm{CGH})$ analysis revealed the expression of sulfotransferase family genes (Sult2a2, Sult2al1, and Sult2a1) was significantly lower intergenerationally and intergenerationally in the procyanidin-treated group compared to the BPA-treated group. Additionally, they discovered that the number of deleted genes increased significantly in the $\mathrm{P}$ generation compared to the F1 generation, while the number of deleted genes decreased significantly in the procyanidin-treated rats in the $\mathrm{P}$ generation compared to the F1 generation. Thus, this study established that procyanidin could mitigate the detrimental effects of BPA on the expression of sulfotransferase family genes across generations.

In another study, researchers examined whether grape seed procyanidin extract can protect testicular cells from oxidative injury caused by varicocele via the nuclear factor (erythroid-derived 2)-like 2 (Nrf2) antioxidant pathway. As a result, they discovered that administering procyanidin significantly improved sperm count and motility, as well as other 
pathological changes associated with varicocele. Apart from that, procyanidin administration partially reversed the decreased antioxidant enzyme activity (superoxide dismutase and glutathione peroxidase) and increased oxidative stress levels, as well as the testis apoptotic level. These findings suggest that procyanidin may be able to alleviate abnormal spermatogenesis and testicular injury in varicocele rats, possibly through its antioxidant activity and ability to activate the Nrf2 pathway [128].

Another study has been conducted to determine whether procyanidin can protect mice from doxorubicin-induced mutagenicity and to delineate the mechanism by which they can do so. In this study, oral administration of procyanidins for seven consecutive days before and seven consecutive days after doxorubicin treatment significantly increased sperm count and motility, which were decreased by doxorubicin treatment. Additionally, procyanidins significantly reduced doxorubicin-induced increases in spermatogonia and spermatocyte chromosomal aberrations and sperm head abnormality. This study demonstrated that procyanidins protect against doxorubicin-induced mutagenesis and cell proliferation changes in mouse germinal cells, suggesting that they may be a good potential chemopreventive agent for cancer patients undergoing doxorubicin-involved treatment [129].

Procyanidin has been shown to improve the quality of eggs, as reported by Barbe and colleagues [130]. They revealed that supplementation with procyanidin had no effect on egg production or fertility parameters. However, it decreased the number of reactive oxygen species and steroidogenesis in yolk eggs. Additionally, they discovered that procyanidin improved egg quality by reducing the number of double-yolk eggs and increasing the size and elasticity of normal eggs. On the other hand, maternal procyanidin intake during lactation resulted in offspring with insulin resistance and an adiponectin resistance-like phenotype [131].

\section{Protective Roles Against Chronic Diseases and Metabolic Disorders}

Procyanidins have been shown in several studies to improve the survival of chronic disease patients by reducing the complications of cardiovascular disease and metabolic syndrome and improving the overall quality of life. Procyanidins inhibit oxidative stress effectively by repairing DNA damage, restricting lipid peroxidation, and activating signaling pathways. However, additional clinical trials are urgently needed to investigate procyanidin's synergistic and antagonistic effects and other drugs [96].

A study reported that procyanidin derived from grape seeds provided great protection against acetaminophen-induced liver and kidney damage by reducing oxidative stress. Additionally, it was reported to provide superior protection against myocardial ischemiareperfusion injury and myocardial infarction in rats and chronic pancreatitis in humans [74]. Other researchers supplemented the diabetic rat model with procyanidins from grapes in another study. Their results indicated that oral administration of procyanidins dramatically improved pancreatic glutathione (GSH) levels and impaired alloxan-induced lipid peroxidation. Apart from that, their findings indicated that procyanidins significantly decreased pancreatic total nitrate/nitrite content and exhibited antihyperglycemic activity by inhibiting alloxan-induced hyperglycemia [132].

Procyanidins also affect glycolytic homeostasis by lowering blood glucose levels and increasing the production of coenzyme A for binding and raising lipoproteins [133]. Cinnamon procyanidins also exhibit anti-diabetic activity in a mouse model, as demonstrated by Sun and colleagues [32]. They discovered that trimer procyanidins in cinnamon extract protect 
pancreatic cells by increasing glucose-stimulated insulin secretion in procyanidin-treated cells and islets and decreasing ROS accumulation in $\mathrm{H}_{2} \mathrm{O}_{2}$-treated islets. Besides this, procyanidins may ameliorate cognitive dysfunction in Sprague-Dawley rats with focal cerebral ischemia, used as a model for type 2 diabetes (T2D) by diminishing STAT1 expression and impeding JAK/STAT signaling [52, 134]. Additionally, procyanidin inhibited the growth of vascular smooth muscle cells induced by high glucose by inhibiting the PI3k/Akt signaling pathway and ROS overproduction [135].

Other researchers discovered that a three-week treatment with procyanidins at lower doses improved insulin resistance indexes, plasma glucose, and insulin levels in rats fed a highfat diet (HFD). Additionally, they discovered that low doses of procyanidins significantly reduced fasting plasma insulin levels after ten and thirty days and decreased glucose levels by 14\% [136-138]. In an obesity study, researchers discovered that chronic administration of procyanidins derived from grape seeds elevated plasma levels of TNF-, IL-6, and monocyte chemotactic protein 1 (MCP-1), all of which promote macrophage accumulation. Additionally, it improved gut health in diet-induced obese rats by decreasing proinflammatory cytokine TNFsecretions, lowering transepithelial electrical resistance in the small and large intestine, and reversing plasma bacterial endotoxins. Likewise, procyanidins were found to inhibit the expression of inflammatory factors such as myeloperoxidase, interleukin-1, interleukin-6, and TNF-in the lung tissue of rats with pulmonary arterial hypertension [109, 139].

Additionally, procyanidins were found to lower both systolic and diastolic blood pressure in rats, as reported by Quinones and colleagues [140]. They demonstrated that administration of procyanidins reduced systolic blood pressure in hypertensive rats when compared to the normotensive group and that the effect was comparable to that of the standard drug captopril. Another study revealed that administration of procyanidin from grape seeds effectively reduced serum cholesterol, LDL, free fatty acids, and TAGs levels while accelerating serum phospholipids and HDL levels in the hypercholesterolemia rat model. Additionally, they discovered that procyanidins improve the activity of enzymes associated with diagnostic cardiac serum markers such as glutamate oxaloacetate transaminase (SGOT), lactate dehydrogenase (LDH), and creatine kinase (CK) [141].

Numerous studies have demonstrated procyanidins' efficacy in preventing and treating cardiovascular diseases such as atherosclerosis, hypertension, heart failure, and restenosis. Procyanidins effectively lowered blood pressure caused by salt and ameliorated cardiovascular remodeling by inhibiting ROS generation and p38MAPK pathway activation. Additionally, it reduces lipid peroxidation, lowers blood pressure, and improves hypertriglyceridemia [52, 142-144].

\section{Antibacterial Effects of Procyanidins}

Procyanidin has been shown to have potential health benefits by having the ability to function as an antibacterial compound against various bacteria, as revealed by Yang and colleagues [52]. They discovered that a procyanidin diet derived from cranberry juice could accelerate $E$. coli agglutination and reduce bacterial invasion in the urinary tract via interactions at the gastrointestinal tract mucosal surface. On another note, research on tea procyanidins revealed that procyanidins could directly or indirectly reduce infection by Staphylococcus aureus, Streptococcus pyogenes, Escherichia coli Helicobacter pylori, and certain other grampositive and gram-negative bacteria. The experiments demonstrated that procyanidins could 
inhibit bacterial growth through various mechanisms, including inhibition of extracellular enzymes, deprivation of essential microbial substrates, bacterial outer membrane disintegration with cytoplasm leakage, and direct action on microbial metabolism [38, 145-147].

Furthermore, a study discovered that the ethanol extract and fractions of $N$. imperialis have anti-diarrheal properties, which may be due to procyanidin and ellagic acid derivatives [148]. Another study discovered that hawthorn methanol extracts inhibit intracellular enzyme activity, damage the cell wall and membrane integrity, increase reactive oxygen species (ROS), change the expression of associated genes, and induce apoptosis in S. aureus [149]. The insilico study found that catechin and procyanidin from $P$. spruceanum leaves and fractions can act as antibacterial agents by damaging the cell wall and changing the cell shape of resistant bacteria [150]. The study also discovered that procyanidins from Pelargonium sidoides root extract exhibited remarkable antibacterial activities against gram-negative keystone dental medicine and peri-implant morbific strains Porphyromonas gingivalis, in an oral bacteria viability study [151].

Other researchers discovered that procyanidin mediates the gut microbiota and intestinal metabolic function, resulting in positive effects on metabolic homeostasis such as carbohydrate, amino acid, energy, and nucleotide metabolism [47]. Procyanidins derived from Pinus pinaster aqueous bark extract were discovered to have potent antibacterial activity against multidrug-resistant Acinetobacter baumannii isolates [152]. In addition, procyanidin fractions from Pelargonium sidoides root extract exhibited strong antibacterial activity against Staphylococcus aureus, Staphylococcus epidermidis, Aggregatibacter actinomycetemcomitans, and Escherichia coli under periodontitis-mimicking conditions, making them promising candidates for periodontitis treatment [153]. As reported by another study, a procyanidin-rich extract prepared from food-grade winery grape seeds was found to possess antibacterial activity against Helicobacter pylori [154].

\section{Antivirus Properties of Procyanidins}

Procyanidins have also been shown to have antiviral activity against a variety of viruses. Procyanidins had antiviral properties against herpes simplex and coxsackie viruses, and their minimal inhibitory concentrations were much higher than the anti-herpes and anticoxsackie references acyclovir or 3-methylquercetin [155]. Furthermore, procyanidins have been shown to inhibit RSV replication by blocking RSV-induced nuclear factor-B, p38 MAPK/JNK, AP-1, and ERK signaling pathways. These experiments also revealed that procyanidins inhibited RSV-induced signaling pathways such as extracellular signal-regulated kinase, c-Jun N-terminal kinase, and activating protein-1 family members, implying that procyanidins could be a potent therapeutic agent to suppress excessive mucus production and viral replication in RSV-induced airway inflammatory disorders [156].

In another study, researchers discovered that procyanidins extracted from tea had inhibitory potential against influenza A and B viruses. They discovered that procyanidins bind to viral envelope glycoproteins to block hemagglutinin domains, inhibiting virus particle agglutination and preventing influenza virions from adsorbing and entering host cells [147, 157]. Aside from that, procyanidins found in tea have been shown to inhibit hepatitis $C$ virus entry and replication in hepatocytes [158, 159]. Furthermore, the antiviral effects of these procyanidins were shown to impede the life cycle of the HIV-1 virus by impairing gp120 binding to human CD4 T cells $[160,161]$. Recent research found that procyanidin may have 
antiviral properties against coronavirus (SARS-CoV-2) by inhibiting the interaction of several proteins during virus entry and replication [162-164].

Blueberry procyanidins fraction has been tested for antiviral activity against human enteric viruses, specifically Aichi virus (AiV), which causes gastroenteritis. Joshi and colleagues discovered and suggested that procyanidins from blueberries can lower AiV titers, potentially preventing AiV-related illnesses and outbreaks [165]. A butanol fraction of Cinnamomi cotex containing procyanidins has also been reported to have inhibitory activity against wild-type SARS-CoV and HIV/SARS-CoV S pseudovirus infection by interfering with endocytosis [166]. Aside from that, researchers discovered that procyanidin-enriched Rumex acetosa extracts had antiviral activity against influenza A viruses by preventing viral entry into the host cell [167]. Researchers discovered that procyanidins from cranberries have inhibitory activity against murine norovirus (MNV-1), feline calicivirus (FCV-F9), MS2 (ssRNA) bacteriophage, and fX-174 (ssDNA) bacteriophage. Within the first 10 minutes of treatment, procyanidins were able to reduce virus titers [168].

\section{Suggestion and Future Directions}

Procyanidin research should be conducted in the future using various in vivo and in vitro models better to understand potential health benefits, metabolism, and toxicity. The procyanidin-gut microbiota interactions should be the main focus, especially on microbiota isolation, identification, and metabolism. Procyanidin metabolism and absorption can be explored using next-generation sequencing or sound in vitro models. Also, other A-and B-type polyphenol metabolites should be investigated for health implications.

\section{Conclusions}

Procyanidin is a polyphenol that occurs naturally in various plants, flowers, nuts, and barks. Procyanidin possesses antioxidant, anticancer, antitumor, anti-inflammatory, immunosuppressive, and antiallergy properties and protective properties against chronic diseases and metabolic disorders. Additionally, extensive research on the health effects, genotoxicity, metabolism, bioavailability, and toxicology is required before recommending a dietary supplement.

\section{Funding}

The research grant from Universiti Teknologi MARA (UiTM) Malaysia, specifically the LESTARI Grant (600-IRMI 5/3/LESTARI (022/2019), was used to fund this study.

\section{Acknowledgments}

The authors wish to convey their appreciation to all staff and contributors at the Faculty of Health Sciences and Faculty of Pharmacy, UiTM Selangor, Puncak Alam Campus; the Faculty of Health Sciences, Universitas' Aisyiyah Bandung, Indonesia; and the Malaysian Agricultural Research and Development Institute (MARDI) for their guidance, insightful suggestions, and unbending enthusiasm in preparing this article. Thank you to the Tun Abdul Razak Library (PTAR) UiTM for establishing a decent online database platform for this review. 


\section{Conflicts of Interest}

The authors declare no conflict of interest.

\section{References}

1. Tsao, R. Chemistry and biochemistry of dietary polyphenols. Nutrients 2010, 2, 1231-1246, https://doi.org/10.3390/nu2121231.

2. Choy, Y.Y.; Waterhouse, A.L. Proanthocyanidin Metabolism, a mini review. Nutr. Aging 2014, 2, 111-116, https://doi.org/10.3233/nua-140038.

3. Nie, Y.; Stürzenbaum, S.R. Proanthocyanidins of Natural Origin: Molecular Mechanisms and Implications for Lipid Disorder and Aging-Associated Diseases. Adv. Nutr. 2019, 10, 464-478, https://doi.org/10.1093/advances/nmy118.

4. Rodríguez-Pérez, C.; García-Villanova, B.; Guerra-Hernández, E.; Verardo, V. Grape seeds proanthocyanidins: An overview of in vivo bioactivity in animal models. Nutrients 2019, 11, 1-18, https://doi.org/10.3390/nu11102435.

5. De Taeye, C.; Cibaka, M.L.K.; Collin, S. Occurrence and antioxidant activity of $\mathrm{c} 1$ degradation products in cocoa. Foods 2017, 6, 1-15, https://doi.org/10.3390/foods6030018.

6. Nakano, N.; Nishiyama, C.; Tokura, T.; Nagasako-Akazome, Y.; Ohtake, Y.; Okumura, K.; Ogawa, H. Procyanidin $\mathrm{C} 1$ from apple extracts inhibits FceRI-mediated mast cell activation. Int. Arch. Allergy Immunol. 2008, 147, 213-221, https://doi.org/10.1159/000142044.

7. Yamashita, Y.; Okabe, M.; Natsume, M.; Ashida, H. Cinnamtannin A2, a tetrameric procyanidin, increases GLP-1 and insulin secretion in mice. Biosci. Biotechnol. Biochem. 2013, 77, 888-891, https://doi.org/10.1271/bbb.130095.

8. Bae, J.; Kumazoe, M.; Murata, K.; Fujimura, Y.; Tachibana, H. Procyanidin C1 Inhibits Melanoma Cell Growth by Activating 67-kDa Laminin Receptor Signaling. Mol. Nutr. Food Res. 2020, 64, 1-9, https://doi.org/10.1002/mnfr.201900986.

9. Izumi, T.; Masakazu, T. The Diverse Efficacy of Food-Derived Proanthocyanidins for Middle-Aged and Elderly Women. Nutrients 2020, 12, 1-17, https://doi.org/10.3390/nu12123833.

10. Rue, E.A.; Rush, M.D.; van Breemen, R.B. Procyanidins: a comprehensive review encompassing structure elucidation via mass spectrometry. Phytochem Rev 2018, 17, 1-16, https://doi.org/10.1007/s11101-0179507-3.Procyanidins.

11. Svedström, U.; Vuorela, H.; Kostiainen, R.; Tuominen, J.; Kokkonen, J.; Rauha, J.P.; Laakso, I.; Hiltunen, R. Isolation and identification of oligomeric procyanidins from Crataegus leaves and flowers. Phytochemistry 2002, 60, 821-825, https://doi.org/10.1016/S0031-9422(02)00172-3.

12. Tao, W.; Zhang, Y.; Shen, X.; Cao, Y.; Shi, J.; Ye, X.; Chen, S. Rethinking the Mechanism of the Health Benefits of Proanthocyanidins: Absorption, Metabolism, and Interaction with Gut Microbiota. Compr. Rev. Food Sci. Food Saf. 2019, 18, 971-985, https://doi.org/10.1111/1541-4337.12444.

13. Yang, B.; Liu, P. Composition and health effects of phenolic compounds in hawthorn (Crataegus spp.) of different origins. J. Sci. Food Agric. 2012, 92, 1578-1590, https://doi.org/10.1002/jsfa.5671.

14. Gu, L.; Kelm, M.; Hammerstone, J.F.; Beecher, G.; Cunningham, D.; Vannozzi, S.; Prior, R.L. Fractionation of Polymeric Procyanidins from Lowbush Blueberry and Quantification of Procyanidins in Selected Foods with an Optimized Normal-Phase HPLC-MS Fluorescent Detection Method. Journal of Agricultural and Food Chemistry 2002, 50, 4852-4860, https://doi.org/10.1021/jf020214v.

15. Ou, K.; Gu, L. Absorption and metabolism of proanthocyanidins. J. Funct. Foods 2014, 7, 43-53, https://doi.org/10.1016/j.jff.2013.08.004.

16. Yokota, K.; Kimura, H.; Ogawa, S.; Akihiro, T. Analysis of A-type and B-type highly polymeric proanthocyanidins and their biological activities as nutraceuticals. J. Chem. 2013, 2013, 1-8, https://doi.org/10.1155/2013/352042.

17. Hori, T.; Barnor, J.; Nguyen Huu, T.; Morinaga, O.; Hamano, A.; Ndzinu, J.; Frimpong, A.; Minta-Asare, K.; Amoa-Bosompem, M.; Brandful, J.; Odoom, J.; Bonney, J.; Tuffour, I.; Owusu, B.-A.; Ofosuhene, M.; Atchoglo, P.; Sakyiamah, M.; Adegle, R.; Appiah-Opong, R.; Ampofo, W.; Koram, K.; Nyarko, A.; Okine, L.; Edoh, D.; Appiah, A.; Uto, T.; Yoshinaka, Y.; Uota, S.; Shoyama, Y.; Yamaoka, S. Procyanidin trimer C1 derived from Theobroma cacao reactivates latent human immunodeficiency virus type 1 provirus. Biochemical and Biophysical Research Communications 2015, 459, 288-293, https://doi.org/10.1016/j.bbrc.2015.02.102.

18. Ito, C.; Oki, T.; Yoshida, T.; Nanba, F.; Yamada, K.; Toda, T. Characterisation of proanthocyanidins from black soybeans: Isolation and characterisation of proanthocyanidin oligomers from black soybean seed coats. Food Chem. 2013, 141, 2507-2512, https://doi.org/10.1016/j.foodchem.2013.05.039.

19. Rios, L.Y.; Bennett, R.N.; Lazarus, S.A.; Rémésy, C.; Scalbert, A.; Williamson, G. Cocoa procyanidins are stable during gastric transit in humans. Am. J. Clin. Nutr. 2002, 76, 1106-1110, https://doi.org/10.1093/ajen/76.5.1106. 
20. Rusconi, M.; Conti, A. Theobroma cacao L., the Food of the Gods: A scientific approach beyond myths and claims. Pharmacological Research 2010, 61, 5-13, https://doi.org/10.1016/j.phrs.2009.08.008.

21. Masuda, I.; Koike, M.; Nakashima, S.; Mizutani, Y.; Ozawa, Y.; Watanabe, K.; Sawada, Y.; Sugiyama, H.; Sugimoto, A.; Nojiri, H.; Sashihara, K.; Yokote, K.; Shimizu, T. Apple procyanidins promote mitochondrial biogenesis and proteoglycan biosynthesis in chondrocytes. Scientific Reports 2018, 8, 1-13, https://doi.org/10.1038/s41598-018-25348-1.

22. Jalil, A.M.M.; Ismail, A. Polyphenols in cocoa and cocoa products: Is there a link between antioxidant properties and health? Molecules 2008, 13, 2190-2219, https://doi.org/10.3390/molecules13092190.

23. Appeldoorn, M. Dietary A-and B-type procyanidins: characterization and biofunctional potential of an abundant and diverse group of phenolics. 2009.

24. Chamorro, F.; Carpena, M.; Nuñez-Estevez, B.; Prieto, M.A.; Simal-Gandara, J. Valorization of Kiwi byProducts for the Recovery of Bioactive Compounds: Circular Economy Model. Proceedings 2020, 70, https://doi.org/10.3390/foods_2020-07647.

25. Li, H.-Y.; Yuan, Q.; Yang, Y.-L.; Han, Q.-H.; He, J.-L.; Zhao, L.; Zhang, Q.; Liu, S.-X.; Lin, D.-R.; Wu, D.T.; Qin, W. Phenolic Profiles, Antioxidant Capacities, and Inhibitory Effects on Digestive Enzymes of Different Kiwifruits. Molecules 2018, 23, 1-16, https://doi.org/10.3390/molecules23112957.

26. Brahem, M.; Renard, C.M.G.C.; Bureau, S.; Watrelot, A.A.; Le Bourvellec, C. Pear ripeness and tissue type impact procyanidin-cell wall interactions. Food Chem. 2019, 275, 754-762, https://doi.org/10.1016/j.foodchem.2018.09.156.

27. Jeong, D.E.; Cho, J.Y.; Lee, Y.G.; Jeong, H.Y.; Lee, H.J.; Moon, J.H. Isolation of five proanthocyanidins from pear (Pyrus pyrifolia Nakai) fruit peels. Food Sci. Biotechnol. 2017, 26, 1209-1215, https://doi.org/10.1007/s10068-017-0157-4.

28. Bennett, R.N.; Shiga, T.M.; Hassimotto, N.M.A.; Rosa, E.A.S.; Lajolo, F.M.; Cordenunsi, B.R. Phenolics and antioxidant properties of fruit pulp and cell wall fractions of postharvest banana (musa acuminata juss.) Cultivars. J. Agric. Food Chem. 2010, 58, 7991-8003, https://doi.org/10.1021/jf1008692.

29. Chen, J.; Li, F.; Li, Y.; Wang, Y.; Wang, C.; Yuan, D.; Jiang, Y. Exogenous procyanidin treatment delays senescence of harvested banana fruit by enhancing antioxidant responses and in vivo procyanidin content. Postharvest Biol. Technol. 2019, 158, https://doi.org/10.1016/j.postharvbio.2019.110999.

30. Materska, M.; Olszówka, K.; Chilczuk, B.; Stochmal, A.; Pecio, Ł.; Pacholczyk-Sienicka, B.; Piacente, S.; Pizza, C.; Masullo, M. Polyphenolic profiles in lettuce (Lactuca sativa L.) after $\mathrm{CaCl} 2$ treatment and cold storage. Eur. Food Res. Technol. 2019, 245, 733-744, https://doi.org/10.1007/s00217-018-3195-0.

31. Kim, M.-J.; Hyun, J.-N.; Kim, J.-A.; Park, J.-C.; Kim, M.-Y.; Kim, J.-G.; Lee, S.-J.; Chun, S.-C.; Chung, I.M. Relationship between Phenolic Compounds, Anthocyanins Content and Antioxidant Activity in Colored Barley Germplasm. Journal of Agricultural and Food Chemistry 2007, 55, 4802-4809, https://doi.org/10.1021/jf0701943.

32. Sun, P.; Wang, T.; Chen, L.; Yu, B.-w.; Jia, Q.; Chen, K.-X.; Fan, H.-m.; Li, Y.-m.; Wang, H.-y. Trimer procyanidin oligomers contribute to the protective effects of cinnamon extracts on pancreatic $\beta$-cells in vitro. Acta Pharmacologica Sinica 2016, 37, 1083-1090, https://doi.org/10.1038/aps.2016.29.

33. Wessels, B.; Damm, S.; Kunz, B.; Schulze-Kaysers, N. Effect of selected plant extracts on the inhibition of enzymatic browning in fresh-cut apple. J Appl Bot Food Qual 2014, 87, 16-23, https://doi.org/10.5073/JABFQ.2014.087.003.

34. Nawrot-Hadzik, I.; Matkowski, A.; Kubasiewicz-Ross, P.; Hadzik, J. Proanthocyanidins and flavan-3-ols in the prevention and treatment of periodontitis-immunomodulatory effects, animal and clinical studies. Nutrients 2021, 13, 1-28, https://doi.org/10.3390/nu13010239.

35. Weinert, C.H.; Wiese, S.; Rawel, H.M.; Esatbeyoglu, T.; Winterhalter, P.; Homann, T.; Kulling, S.E. Methylation of catechins and procyanidins by rat and human catechol-o-methyltransferase: Metabolite profiling and molecular modeling studies. Drug Metab. Dispos. 2012, 40, 353-359, https://doi.org/10.1124/dmd.111.041871.

36. Bohn, T. Dietary factors affecting polyphenol bioavailability. Nutr. Rev. 2014, 72, 429-452, https://doi.org/10.1111/nure.12114.

37. Chen, X.X.; Feng, H.L.; Ding, Y.M.; Chai, W.M.; Xiang, Z.H.; Shi, Y.; Chen, Q.X. Structure characterization of proanthocyanidins from Caryota ochlandra Hance and their bioactivities. Food Chem. 2014, 155, 1-8, https://doi.org/10.1016/j.foodchem.2014.01.011.

38. Feliciano, R.P.; Krueger, C.G.; Reed, J.D. Methods to determine effects of cranberry proanthocyanidins on extraintestinal infections: Relevance for urinary tract health. Mol. Nutr. Food Res. 2015, 59, 1292-1306, https://doi.org/10.1002/mnfr.201500108.

39. Molinar-Toribio, E.; Ramos-Romero, S.; Fuguet, E.; Taltavull, N.; Méndez, L.; Romeu, M.; Medina, I.; Torres, J.L.; Pérez-Jiménez, J. Influence of omega-3 PUFAs on the metabolism of proanthocyanidins in rats. Food Res. Int. 2017, 97, 133-140, https://doi.org/10.1016/j.foodres.2017.03.046.

40. Scalbert, A.; Morand, C.; Manach, C.; Rémésy, C. Absorption and metabolism of polyphenols in the gut and impact on health. Biomed Pharmacother 2002, 56, 276-282, https://doi.org/10.1016/S0753-3322(02)002056. 
41. Zhang, L.; Wang, Y.; Li, D.; Ho, C.T.; Li, J.; Wan, X. The absorption, distribution, metabolism and excretion of procyanidins. Food Funct. 2016, 7, 1273-1281, https://doi.org/10.1039/c5fo01244a.

42. Manach, C.; Williamson, G.; Morand, C.; Scalbert, A.; Rémésy, C. Bioavailability and bioefficacy of polyphenols in humans. I. Review of 97 bioavailability studies. Am. J. Clin. Nutr. 2005, 81, 230-242, https://doi.org/10.1093/ajen/81.1.230s.

43. Touriño, S.; Pérez-Jiménez, J.; Mateos-Martín, M.L.; Fuguet, E.; Vinardell, M.P.; Cascante, M.; Torres, J.L. Metabolites in contact with the rat digestive tract after ingestion of a phenolic-rich dietary fiber matrix. $J$. Agric. Food Chem. 2011, 59, 5955-5963, https://doi.org/10.1021/jf200159f.

44. Mateos-Martín, M.L.; Pérez-Jiménez, J.; Fuguet, E.; Torres, J.L. Profile of urinary and fecal proanthocyanidin metabolites from common cinnamon (Cinnamomum zeylanicum L.) in rats. Mol. Nutr. Food Res. 2012, 56, 671-675, https://doi.org/10.1002/mnfr.201100672.

45. Monagas, M.; Urpi-Sarda, M.; Sánchez-Patán, F.; Llorach, R.; Garrido, I.; Gómez-Cordovés, C.; AndresLacueva, C.; Bartolomé, B. Insights into the metabolism and microbial biotransformation of dietary flavan3-ols and the bioactivity of their metabolites. Food Funct. 2010, 1, 233-253, https://doi.org/10.1039/c0fo00132e.

46. Ou, K.; Sarnoski, P.; Schneider, K.R.; Song, K.; Khoo, C.; Gu, L. Microbial catabolism of procyanidins by human gut microbiota. Mol. Nutr. Food Res. 2014, 58, 2196-2205, https://doi.org/10.1002/mnfr.201400243.

47. Zhao, T.; Shen, X.; Dai, C.; Cui, L. Benefits of procyanidins on gut microbiota in Bama minipigs and implications in replacing antibiotics. J. Vet. Sci. 2018, 19, 798-807, https://doi.org/10.4142/jvs.2018.19.6.798.

48. Kelly, C.R.; Khoruts, A.; Staley, C.; Sadowsky, M.J.; Abd, M.; Alani, M.; Bakow, B.; Curran, P.; McKenney, J.; Tisch, A.; Reinert, S.E.; Machan, J.T.; Brandt, L.J. Effect of Fecal Microbiota Transplantation on Recurrence in Multiply Recurrent Clostridium difficile Infection. Annals of Internal Medicine 2016, 165, 609-616, https://doi.org/10.7326/M16-0271.

49. Qi, X.; Li, X.; Zhao, Y.; Wu, X.; Chen, F.; Ma, X.; Zhang, F.; Wu, D. Treating steroid refractory intestinal acute graft-vs.-Host disease with fecal microbiota transplantation: A pilot study. Front. Immunol. 2018, 9, 17, https://doi.org/10.3389/fimmu.2018.02195.

50. Bagchi, D.; Garg, A.; Krohn, R.L.; Bagchi, M.; Tran, M.X.; Stohs, S.J. Oxygen free radical scavenging abilities of vitamins $\mathrm{C}$ and $\mathrm{E}$, and a grape seed proanthocyanidin extract in vitro. Res. Commun. Mol. Pathol. Pharmacol. 1997, 95, 179-189.

51. Gao, W.; Jin, Y.; Hao, J.; Huang, S.; Wang, D.; Quan, F.; Ren, W.; Zhang, J.; Zhang, M.; Yu, X. Procyanidin B1 promotes in vitro maturation of pig oocytes by reducing oxidative stress. Mol. Reprod. Dev. 2021, 88, 5566, https://doi.org/10.1002/mrd.23440.

52. Yang, L.; Xian, D.; Xiong, X.; Lai, R.; Song, J.; Zhong, J. Proanthocyanidins against oxidative stress: From molecular mechanisms to clinical applications. Biomed Res. Int. 2018, 2018, https://doi.org/10.1155/2018/8584136.

53. Sies, H.; Jones, D.P. Reactive oxygen species (ROS) as pleiotropic physiological signalling agents. Nat. Rev. Mol. Cell Biol. 2020, 21, 363-383, https://doi.org/10.1038/s41580-020-0230-3.

54. Xu, Q.; Fu, Q.; Li, Z.; Liu, H.; Wang, Y.; Lin, X.; He, R.; Zhang, X.; Campisi, J.; Kirkland, J.L.; Sun, Y. Procyanidin $\mathrm{C} 1$ is a natural agent with senolytic activity against aging and age-related diseases. bioRxiv 2021, https://doi.org/10.1101/2021.04.14.439765.

55. Colavitti, R.; Pani, G.; Bedogni, B.; Anzevino, R.; Borrello, S.; Waltenberger, J.; Galeotti, T. Reactive oxygen species as downstream mediators of angiogenic signaling by vascular endothelial growth factor receptor2/KDR. J. Biol. Chem. 2002, 277, 3101-3108, https://doi.org/10.1074/jbc.M107711200.

56. Jha, N.; Ryu, J.J.; Choi, E.H.; Kaushik, N.K. Generation and role of reactive oxygen and nitrogen species induced by plasma, lasers, chemical agents, and other systems in dentistry. Oxid. Med. Cell. Longev. 2017, 2017, https://doi.org/10.1155/2017/7542540.

57. Pi, X.; Xie, L.; Portbury, A.L.; Kumar, S.; Lockyer, P.; Li, X.; Patterson, C. NADPH oxidase-generated reactive oxygen species are required for stromal cell-derived factor-1 $\alpha$-stimulated angiogenesis. Arterioscler. Thromb. Vasc. Biol. 2014, 34, 2023-2032, https://doi.org/10.1161/ATVBAHA.114.303733.

58. Zhang, J.; Wang, X.; Vikash, V.; Ye, Q.; Wu, D.; Liu, Y.; Dong, W. ROS and ROS-Mediated Cellular Signaling. Oxid. Med. Cell. Longev. 2016, 2016, https://doi.org/10.1155/2016/4350965.

59. Ayala, A.; Muñoz, M.F.; Argüelles, S. Lipid Peroxidation: Production, Metabolism, and Signaling Mechanisms of Malondialdehyde and 4-Hydroxy-2-Nonenal Antonio. Oxidative Med. Cell. Longev. H+ 2014, 1-32, https://doi.org/10.1007/978-3-211-33303-7_2.

60. Brennan, L.A.; Morris, G.M.; Wasson, G.R.; Hannigan, B.M.; Barnett, Y.A. The effect of vitamin C or vitamin E supplementation on basal and $\mathrm{H} 2 \mathrm{O} 2$-induced DNA damage in human lymphocytes. Br. J. Nutr. 2000, 84, 195-202, https://doi.org/10.1017/s0007114500001422.

61. Itri, R.; Junqueira, H.C.; Mertins, O.; Baptista, M.S. Membrane changes under oxidative stress: The impact of oxidized lipids. Biophys. Rev. 2014, 6, 47-61, https://doi.org/10.1007/s12551-013-0128-9.

62. Long, M.; Yang, S.H.; Han, J.X.; Li, P.; Zhang, Y.; Dong, S.; Chen, X.; Guo, J.; Wang, J.; He, J.B. The protective effect of grape-seed proanthocyanidin extract on oxidative damage induced by zearalenone in kunming mice liver. Int. J. Mol. Sci. 2016, 17, https://doi.org/10.3390/ijms17060808. 
63. Mittal, A.; Elmets, C.A.; Katiyar, S.K. Dietary feeding of proanthocyanidins from grape seeds prevents photocarcinogenesis in SKH-1 hairless mice: Relationship to decreased fat and lipid peroxidation. Carcinogenesis 2003, 24, 1379-1388, https://doi.org/10.1093/carcin/bgg095.

64. Bakheet, S.A.; Alhuraishi, A.M.; Al-Harbi, N.O.; Al-Hosaini, K.A.; Al-Sharary, S.D.; Attia, M.M.; Alhoshani, A.R.; Al-Shabanah, O.A.; Al-Harbi, M.M.; Imam, F.; Ahmad, S.F.; Attia, S.M. Alleviation of Aflatoxin B1-Induced Genomic Damage by Proanthocyanidins via Modulation of DNA Repair. Journal of Biochemical and Molecular Toxicology 2016, 30, 559-566, https://doi.org/10.1002/jbt.21823.

65. Nichols, J.A.; Katiyar, S.K. Skin photoprotection by natural polyphenols: Anti-inflammatory, antioxidant and DNA repair mechanisms. Arch. Dermatol. Res. 2010, 302, 71-83, https://doi.org/10.1007/s00403-009-10013.

66. Katiyar, S.K.; Pal, H.C.; Prasad, R. Dietary proanthocyanidins prevent ultraviolet radiation-induced nonmelanoma skin cancer through enhanced repair of damaged DNA-dependent activation of immune sensitivity. Semin. Cancer Biol. 2017, 46, 138-145, https://doi.org/10.1016/j.semcancer.2017.04.003.

67. Vaid, M.; Prasad, R.; Singh, T.; Katiyar, S.K. Dietary grape seed proanthocyanidins inactivate regulatory T cells by promoting NER-dependent DNA repair in dendritic cells in UVB-exposed skin. Oncotarget 2017, 8, 49625-49636, https://doi.org/10.18632/oncotarget.17867.

68. Bak, M.J.; Truong, V.L.; Ko, S.Y.; Nguyen, X.N.G.; Ingkasupart, P.; Jun, M.; Shin, J.Y.; Jeong, W.S. Antioxidant and hepatoprotective effects of procyanidins from wild grape (Vitis amurensis) seeds in ethanolinduced cells and rats. Int. J. Mol. Sci. 2016, 17, 1-16, https://doi.org/10.3390/ijms17050758.

69. Kim, H.; Kim, J.Y.; Song, H.S.; Park, K.U.; Mun, K.C.; Ha, E. Grape seed proanthocyanidin extract inhibits interleukin-17-induced interleukin-6 production via MAPK pathway in human pulmonary epithelial cells. Naunyn. Schmiedebergs. Arch. Pharmacol. 2011, 383, 555-562, https://doi.org/10.1007/s00210-011-0633$\mathrm{y}$.

70. Fernández-Iglesias, A.; Quesada, H.; Díaz, S.; Pajuelo, D.; Bladé, C.; Arola, L.; Salvadó, M.J.; Mulero, M. Combination of grape seed proanthocyanidin extract and docosahexaenoic acid-rich oil increases the hepatic detoxification by GST mediated GSH conjugation in a lipidic postprandial state. Food Chem. 2014, 165, 1420, https://doi.org/10.1016/j.foodchem.2014.05.057.

71. Nimse, S.B.; Pal, D. Free radicals, natural antioxidants, and their reaction mechanisms. RSC Adv. 2015, 5, 27986-28006, https://doi.org/10.1039/c4ra13315c.

72. Nazima, B.; Manoharan, V.; Miltonprabu, S. Oxidative stress induced by cadmium in the plasma, erythrocytes and lymphocytes of rats: Attenuation by grape seed proanthocyanidins. Hum. Exp. Toxicol. 2016, 35, 428-447, https://doi.org/10.1177/0960327115591376.

73. Jurikova, T.; Sochor, J.; Rop, O.; Mlcek, J.; Balla, S.; Szekeres, L.; Adam, V.; Kizek, R. Polyphenolic profile and biological activity of chinese hawthorn (Crataegus pinnatifida BUNGE) fruits. Molecules 2012, 17, 14490-14509, https://doi.org/10.3390/molecules171214490.

74. Bagchi, D.; Bagchi, M.; Stohs, S.J.; Das, D.K.; Ray, S.D.; Kuszynski, C.A.; Joshi, S.S.; Pruess, H.G. Free radicals and grape seed proanthocyanidin extract: Importance in human health and disease prevention. Toxicology 2000, 148, 187-197, https://doi.org/10.1016/S0300-483X(00)00210-9.

75. Faria, A.; Calhau, C.; De Freitas, V.; Mateus, N. Procyanidins as antioxidants and tumor cell growth modulators. J. Agric. Food Chem. 2006, 54, 2392-2397, https://doi.org/10.1021/jf0526487.

76. Byun, E.-B.; Sung, N.-Y.; Byun, E.-H.; Song, D.-S.; Kim, J.-K.; Park, J.-H.; Song, B.-S.; Park, S.-H.; Lee, J.-W.; Byun, M.-W.; Kim, J.-H. The procyanidin trimer C1 inhibits LPS-induced MAPK and NF- $\kappa B$ signaling through TLR4 in macrophages. International Immunopharmacology 2013, 15, 450-456, https://doi.org/10.1016/j.intimp.2012.11.021.

77. Byun, M.W. Effect of procyanidin $\mathrm{c} 1$ on nitric oxide production and hyperpolarization through $\mathrm{Ca} 2+-$ dependent pathway in endothelial cells. J. Med. Food 2012, 15, 1032-1037, https://doi.org/10.1089/jmf.2012.2297.

78. Felty, Q.; Singh, K.P.; Roy, D. Estrogen-induced G1/S transition of G0-arrested estrogen-dependent breast cancer cells is regulated by mitochondrial oxidant signaling. Oncogene 2005, 24, 4883-4893, https://doi.org/10.1038/sj.onc.1208667.

79. Sosa, V.; Moliné, T.; Somoza, R.; Paciucci, R.; Kondoh, H.; LLeonart, M.E. Oxidative stress and cancer: An overview. Ageing Res. Rev. 2013, 12, 376-390, https://doi.org/10.1016/j.arr.2012.10.004.

80. Waris, G.; Ahsan, H. Reactive oxygen species: Role in the development of cancer and various chronic conditions. J. Carcinog. 2006, 5, 1-8, https://doi.org/10.1186/1477-3163-5-14.

81. Arun, S.N.; Kaddour-Djebbar, I.; Shapiro, B.A.; Bollag, W.B. Ultraviolet B irradiation and activation of protein kinase D in primary mouse epidermal keratinocytes. Oncogene 2011, 30, 1586-1596, https://doi.org/10.1038/onc.2010.540.

82. Ji, H.; Li, X.K. Oxidative Stress in Atopic Dermatitis. Oxid. Med. Cell. Longev. 2016, 2016, https://doi.org/10.1155/2016/2721469.

83. Massi, D.; Franchi, A.; Sardi, I.; Magnelli, L.; Paglierani, M.; Borgognoni, L.; Reali, U.M.; Santucci, M. Inducible nitric oxide synthase expression in benign and malignant cutaneous melanocytic lesions. J. Pathol. 2001, 194, 194-200, https://doi.org/10.1002/1096-9896(200106)194:2<194::AID-PATH851>3.0.CO;2-S. 
84. Moseley, R.; Hilton, J.R.; Waddington, R.J.; Harding, K.G. Comparison of oxidative stress biomarker profiles between acute and chronic wound environments RYAN. Wound Repair Regen. 2004, 12, 419-429, https://doi.org/10.1111/j.1067-1927.2004.12406.x.

85. Wenk, J.; Brenneisen, P.; Meewes, C.; Wlaschek, M.; Peters, T.; Blaudschun, R.; Kuhr, L.; Schneider, L. UV-Induced Oxidative Stress and Photoaging. Curr Probl Dermatol. 2001, 29, 83-94.

86. Nandakumar, V.; Singh, T.; Katiyar, S.K. Multi-targeted prevention and therapy of cancer by proanthocyanidins. Cancer Letters 2008, 269, 378-387, https://doi.org/10.1016/j.canlet.2008.03.049.

87. Siomek, A. NF-кB signaling pathway and free radical impact. Acta Biochim. Pol. 2012, 59, 323-331, https://doi.org/10.18388/abp.2012_2116.

88. Terra, X.; Palozza, P.; Fernandez-Larrea, J.; Ardevol, A.; Blade, C.; Pujadas, G.; Salvado, J.; Arola, L.; Blay, M.T. Procyanidin dimer B1 and trimer C1 impair inflammatory response signalling in human monocytes. Free Radic. Res. 2011, 45, 611-619, https://doi.org/10.3109/10715762.2011.564165.

89. Mantena, S.K.; Katiyar, S.K. Grape seed proanthocyanidins inhibit UV-radiation-induced oxidative stress and activation of MAPK and NF-кB signaling in human epidermal keratinocytes. Free Radic. Biol. Med. 2006, 40, 1603-1614, https://doi.org/10.1016/j.freeradbiomed.2005.12.032.

90. Praud, D.; Parpinel, M.; Guercio, V.; Bosetti, C.; Serraino, D.; Facchini, G.; Montella, M.; La Vecchia, C.; Rossi, M. Proanthocyanidins and the risk of prostate cancer in Italy. Cancer Causes Control 2018, 29, 261268, https://doi.org/10.1007/s10552-018-1002-7.

91. Tyagi, A.; Kumar, S.; Raina, K.; Wempe, M.F.; Maroni, P.D.; Agarwal, R.; Agarwal, C. Differential effect of grape seed extract and its active constituent Procyanidin B2 3, 3"-di-O-gallate against prostate cancer stem cells. Mol Carcinog. 2019, 58, 1105-1117, https://doi.org/10.1002/mc.22995.

92. Ravindranathan, P.; Pasham, D.; Balaji, U.; Cardenas, J.; Gu, J.; Toden, S.; Goel, A. Mechanistic insights into anticancer properties of oligomeric proanthocyanidins from grape seeds in colorectal cancer. Carcinogenesis 2018, 39, 767-777, https://doi.org/10.1093/carcin/bgy034.

93. Minker, C.; Duban, L.; Karas, D.; Järvinen, P.; Lobstein, A.; Muller, C.D. Impact of procyanidins from different berries on caspase 8 activation in colon cancer. Oxid. Med. Cell. Longev. 2015, 2015, https://doi.org/10.1155/2015/154164.

94. Cheah, K.Y.; Howarth, G.S.; Bindon, K.A.; Kennedy, J.A.; Bastian, S.E.P. Low molecular weight procyanidins from grape seeds enhance the impact of 5-Fluorouracil chemotherapy on Caco-2 human colon cancer cells. PLoS One 2014, 9, https://doi.org/10.1371/journal.pone.0098921.

95. Choy, Y.Y.; Fraga, M.; Mackenzie, G.G.; Waterhouse, A.L.; Cremonini, E.; Oteiza, P.I. The PI3K/Akt pathway is involved in procyanidin-mediated suppression of human colorectal cancer cell growth. Mol. Carcinog. 2016, 55, 2196-2209, https://doi.org/10.1002/mc.22461.

96. Wang, T.K.; Xu, S.; Li, S.; Zhang, Y. Proanthocyanidins Should Be a Candidate in the Treatment of Cancer, Cardiovascular Diseases and Lipid Metabolic Disorder. Molecules 2020, 25, 1-22, https://doi.org/10.3390/molecules25245971.

97. Li, Y.; Lu, X.; Tian, P.; Wang, K.; Shi, J. Procyanidin B2 induces apoptosis and autophagy in gastric cancer cells by inhibiting Akt/mTOR signaling pathway. BMC Complement. Med. Ther. 2021, 21, 1-9, https://doi.org/10.1186/s12906-021-03225-1.

98. de Gouveia Cordeiro, Y.; Rochetti, A.L.; Souza, V.C.; da Silva, E.R.; Scatolini, A.M.; Genovese, M.I.; Yasui, G.S.; Fukumasu, H. Antineoplastic effect of procyanidin-rich extract of Lafoensia Pacari in lung carcinoma cells. Brazilian Arch. Biol. Technol. 2019, 62, 1-13, https://doi.org/10.1590/1678-4324-2019160638.

99. Yang, H.; Fang, Z.; Qu, X.; Zhang, X.; Wang, Y. Procyanidin compound (PC) suppresses lipopolysaccharideinduced cervical cancer cell proliferation through blocking the TLR4/NF-кB pathway. Cancer Manag. Res. 2020, 12, 497-509, https://doi.org/10.2147/CMAR.S226547.

100.Kong, F.T.; He, C.X.; Kong, F.L.; Han, S.F.; Kong, X.S.; Han, W.Q.; Yang, L.X. Grape Seed Procyanidins Inhibit the Growth of Breast Cancer MCF-7 Cells by Down-Regulating the EGFR/VEGF/MMP9 Pathway. Nat. Prod. Commun. 2021, 16, https://doi.org/10.1177/1934578X21991691.

101.Wu, Y.Y.; Cao, T.T.; Liu, C.L. Combined effect of vorinostat and grape seed proanthocyanidins on modulation of thymidine phosphorylase in non-small cell lung cancer. Trop. J. Pharm. Res. 2015, 14, 953959, https://doi.org/10.4314/tjpr.v14i6.3.

102.Liu, J.; Zhang, W.Y.; Kong, Z.H.; Ding, D.G. Induction of cell cycle arrest and apoptosis by grape seed procyanidin extract in human bladder cancer BIU87 cells. Eur. Rev. Med. Pharmacol. Sci. 2016, 20, 32823291.

103.Pierini, R.; Kroon, P.A.; Guyot, S.; Ivory, K.; Johnson, I.T.; Belshaw, N.J. Procyanidin effects on oesophageal adenocarcinoma cells strongly depend on flavan-3-ol degree of polymerization. Mol. Nutr. Food Res. 2008, 52, 1399-1407, https://doi.org/10.1002/mnfr.200700513.

104.Katiyar, S.; Elmets, C.A.; Katiyar, S.K. Green tea and skin cancer: photoimmunology, angiogenesis and DNA repair. J. Nutr. Biochem. 2007, 18, 287-296, https://doi.org/10.1016/j.jnutbio.2006.08.004.

105.Chu, H.; Tang, Q.; Huang, H.; Hao, W.; Wei, X. Grape-seed proanthocyanidins inhibit the lipopolysaccharide-induced inflammatory mediator expression in RAW264.7 macrophages by suppressing MAPK and NF-kb signal pathways. Environ. Toxicol. Pharmacol. 2016, 41, 159-166, https://doi.org/10.1016/j.etap.2015.11.018. 
106.Limtrakul, P.; Yodkeeree, S.; Pitchakarn, P.; Punfa, W. Anti-inflammatory effects of proanthocyanidin-rich red rice extract via suppression of MAPK, AP-1 and NF-кB pathways in Raw 264.7 macrophages. Nutr. Res. Pract. 2016, 10, 251-258, https://doi.org/10.4162/nrp.2016.10.3.251.

107.Wang, T.; Zhang, X.; Li, J.J. The role of NF-אB in the regulation of cell stress responses. Int. Immunopharmacol. 2002, 2, 1509-1520, https://doi.org/10.1016/S1567-5769(02)00058-9.

108.Liu, W.; Xu, C.; Sun, X.; Kuang, H.; Kuang, X.; Zou, W.; Yang, B.; Wu, L.; Liu, F.; Zou, T.; Zhang, D. Grape seed proanthocyanidin extract protects against perfluorooctanoic acid-induced hepatotoxicity by attenuating inflammatory response, oxidative stress and apoptosis in mice. Toxicology Research 2016, 5, 224234, https://doi.org/10.1039/c5tx00260e.

109.González-Quilen, C.; Rodríguez-Gallego, E.; Beltrán-Debón, R.; Pinent, M.; Ardévol, A.; Blay, M.T.; Terra, X. Health-Promoting Properties of Proanthocyanidins for Intestinal Dysfunction. Nutrients 2020, 12, https://doi.org/10.3390/nu12010130.

110.Sung, N.-Y.; Yang, M.-S.; Song, D.-S.; Byun, E.-B.; Kim, J.-K.; Park, J.-H.; Song, B.-S.; Lee, J.-W.; Park, S.-H.; Park, H.-J.; Byun, M.-W.; Byun, E.-H.; Kim, J.-H. The procyanidin trimer C1 induces macrophage activation via NF- $\mathrm{BB}$ and MAPK pathways, leading to Th1 polarization in murine splenocytes. European Journal of Pharmacology 2013, 714, 218-228, https://doi.org/10.1016/j.ejphar.2013.02.059.

111.He, J.; Sun, M.; Tian, S. Procyanidin B2 prevents lupus nephritis development in mice by inhibiting NLRP3 inflammasome activation. Innate Immunity 2018, 24, 307-315, https://doi.org/10.1177/1753425918780985.

112.Chen, L.; Yang, Y.; Yuan, P.; Yang, Y.; Chen, K.; Jia, Q.; Li, Y. Immunosuppressive effects of A-type procyanidin oligomers from Cinnamomum tamala. Evidence-based Complement. Altern. Med. 2014, 2014, https://doi.org/10.1155/2014/365258.

113. Katiyar, S.K. Proanthocyanidins from grape seeds inhibit UV-radiation-induced immune suppression in mice: Detection and analysis of molecular and cellular targets. Photochem. Photobiol. 2015, 91, 156-162, https://doi.org/10.1111/php.12330.

114. Miyake, M.; Sasaki, K.; Ide, K.; Matsukura, Y.; Shijima, K.; Fujiwara, D. Highly Oligomeric Procyanidins Ameliorate Experimental Autoimmune Encephalomyelitis via Suppression of Th1 Immunity. J. Immunol. 2006, 176, 5797-5804, https://doi.org/10.4049/jimmunol.176.10.5797.

115.Lai, R.; Xian, D.; Xiong, X.; Yang, L.; Song, J.; Zhong, J. Proanthocyanidins: Novel treatment for psoriasis that reduces oxidative stress and modulates Th17 and Treg cells. Redox Rep. 2018, 23, 130-135, https://doi.org/10.1080/13510002.2018.1462027.

116.Cai, Y.; Kong, H.; Pan, Y.B.; Jiang, L.; Pan, X.X.; Hu, L.; Qian, Y.N.; Jiang, C.Y.; Liu, W.T. Procyanidins alleviates morphine tolerance by inhibiting activation of NLRP3 inflammasome in microglia. $J$. Neuroinflammation 2016, 13, 1-14, https://doi.org/10.1186/s12974-016-0520-z.

117. Soleimani, M.; Masoumi, N. The effect of grape seed extract on semen oxidative stress markers in men with idiopathic infertility: A cross-sectional before-after study. Nephrourol. Mon. 2017, 9, https://doi.org/10.5812/numonthly.13837.

118. Avdatek, F.; Yeni, D.; Tasdemir, U. Influence of Proanthocyanidin on Motility and Osmotic Resistance Parameters of Merino Ram Sperm During Short Term Storage. Kocatepe Vet. J. 2020, 13, 362-367, https://doi.org/10.30607/kvj.800186.

119.Li, Q.; Shaoyong, W.; Li, Y.; Chen, M.; Hu, Y.M.; Liu, B.; Yang, G.S.; Hu, J.H. Effects of oligomeric proanthocyanidins on quality of boar semen during liquid preservation at $17^{\circ}$ C. Anim. Reprod. Sci. 2018, 198, 47-56, https://doi.org/10.1016/j.anireprosci.2018.08.047.

120.Wen, F.; Li, Y.; Feng, T.; Du, Y.; Ren, F.; Zhang, L.; Han, N.; Ma, S.; Li, F.; Wang, P.; Hu, J. Grape Seed Procyanidin Extract (GSPE) Improves Goat Sperm Quality When Preserved at $4{ }^{\circ} \mathrm{C}$. Animals 2019, 9, 1-11, https://doi.org/10.3390/ani9100810.

121. Ansa, A.A.; Akpere, O.; Imasuen, J.A. Características do sêmen, morfometria testicular e histopatologia de cadáveres de coelho expostos, administrado extrato metanólico de frutos de Phoenix dactylifera. Acta Sci. Anim. Sci. 2017, 39, 207-215, https://doi.org/10.4025/actascianimsci.v39i2.32858.

122.Khattab, A.H.; Abdallah, Z.A.; Kamel, M. Grape seed extract alleviate reproductive toxicity caused by aluminium chloride in male rats. Journal of American Science 2010, 6, 1200-1209.

123.Wang, E.H.; Yu, Z.L.; Bu, Y.J.; Xu, P.W.; Xi, J.Y.; Liang, H.Y. Grape seed proanthocyanidin extract alleviates high-fat diet induced testicular toxicity in rats. $R S C A d v$. 2019, 9, 11842-11850, https://doi.org/10.1039/c9ra01017c.

124.Su, L.; Deng, Y.; Zhang, Y.; Li, C.; Zhang, R.; Sun, Y.; Zhang, K.; Li, J.; Yao, S. Protective effects of grape seed procyanidin extract against nickel sulfate-induced apoptosis and oxidative stress in rat testes. Toxicol. Mech. Methods 2011, 21, 487-494, https://doi.org/10.3109/15376516.2011.556156.

125.Del Bas, J.M.; Crescenti, A.; Arola-Arnal, A.; Oms-Oliu, G.; Arola, L.; Caimari, A. Grape seed procyanidin supplementation to rats fed a high-fat diet during pregnancy and lactation increases the body fat content and modulates the inflammatory response and the adipose tissue metabolism of the male offspring in youth. Int. J. Obes. 2015, 39, 7-15, https://doi.org/10.1038/ijo.2014.159.

126. Hassan, H.A.; Isa, A.M.; El-Kholy, W.M.; Nour, S.E. Testicular disorders induced by plant growth regulators: Cellular protection with proanthocyanidins grape seeds extract. Cytotechnology 2013, 65, 851-862, https://doi.org/10.1007/s10616-012-9525-3. 
127.Zulazlan, S.-A.; Dasiman, R.; Mahmud, M.H.; Othman, F.N.; Ismail, N.H.; Zakaria, F.N.; Hshim, N.K.; Malek, M.A. The intergenerational effects of oligomeric proanthocyanidins on expression of Sult2a2, Sult2al1 and Sult2a1 in Bisphenol A-exposed male rats. Curr. Top. Toxicol. 2020, 16, 1-10.

128.Wang, Y.; Chen, F.; Liang, M.; Chen, S.; Zhu, Y.; Zou, Z.; Shi, B. Grape seed proanthocyanidin extract attenuates varicocele-induced testicular oxidative injury in rats by activating the Nrf2-antioxidant system. Mol. Med. Rep. 2018, 17, 1799-1806, https://doi.org/10.3892/mmr.2017.8020.

129.Attia, S.M.; Bakheet, S.A.; Al-Rasheed, N.M. Proanthocyanidins produce significant attenuation of doxorubicin-induced mutagenicity via suppression of oxidative stress. Oxid. Med. Cell. Longev. 2010, 3, 404413, https://doi.org/10.4161/oxim.3.6.14418.

130.Barbe, A.; Mellouk, N.; Ramé, C.; Grandhaye, J.; Anger, K.; Chahnamian, M.; Ganier, P.; Brionne, A.; Riva, A.; Froment, P.; Dupont, J. A grape seed extract maternal dietary supplementation improves egg quality and reduces ovarian steroidogenesis without affecting fertility parameters in reproductive hens. Plos One 2020, 15, 1-22, https://doi.org/10.1371/journal.pone.0233169.

131.Caimari, A.; Mariné-Casadó, R.; Boqué, N.; Crescenti, A.; Arola, L.; Del Bas, J.M. Maternal intake of grape seed procyanidins during lactation induces insulin resistance and an adiponectin resistance-like phenotype in rat offspring. Sci. Rep. 2017, 7, 1-15, https://doi.org/10.1038/s41598-017-12597-9.

132.El-Alfy, A.T.; Ahmed, A.A.E.; Fatani, A.J. Protective effect of red grape seeds proanthocyanidins against induction of diabetes by alloxan in rats. Pharmacol. Res. 2005, 52, 264-270, https://doi.org/10.1016/j.phrs.2005.04.003.

133.Vargas F, V.; Guisado Requena, I.M.; Canadas De la Fuente, G.A.; Castillo, R.F.; Sanchez, E.F.; Jara, C.C.; Guisado Barrilao, R. Effects of Combinational Procyanidins in Grape Seed Extract and Exercise on the Levels of Glucose and Blood Lipid Profile. J. Diabetes Metab. 2017, 08, 6-10, https://doi.org/10.4172/21556156.1000754.

134.Dudley, A.C.; Thomas, D.; Best, J.; Jenkins, A. The STATs in cell stress-type responses. Cell Commun. Signal. 2004, 2, 1-5, https://doi.org/10.1186/1478-811X-2-8.

135.Wang, L.; Zhu, L.H.; Jiang, H.; Tang, Q.Z.; Yan, L.; Wang, D.; Liu, C.; Bian, Z.Y.; Li, H. Grape seed proanthocyanidins attenuate vascular smooth muscle cell proliferation via blocking phosphatidylinositol 3kinase-dependent signaling pathways. J. Cell. Physiol. 2010, 223, 713-726, https://doi.org/10.1002/jcp.22080.

136. Montagut, G.; Baiges, I.; Valls, J.; Terra, X.; del Bas, J.M.; Vitrac, X.; Richard, T.; Mérillon, J.-M.; Arola, L.; Blay, M.; Bladé, C.; Fernández-Larrea, J.; Pujadas, G.; Salvadó, J.; Ardévol, A. A trimer plus a dimergallate reproduce the bioactivity described for an extract of grape seed procyanidins. Food Chemistry 2009, 116, 265-270, https://doi.org/10.1016/j.foodchem.2009.02.044.

137.Pascual-Serrano, A.; Arola-Arnal, A.; Suárez-García, S.; Bravo, F.I.; Suárez, M.; Arola, L.; Bladé, C. Grape seed proanthocyanidin supplementation reduces adipocyte size and increases adipocyte number in obese rats. Int. J. Obes. 2017, 41, 1246-1255, https://doi.org/10.1038/ijo.2017.90.

138.Terra, X.; Montagut, G.; Bustos, M.; Llopiz, N.; Ardèvol, A.; Bladé, C.; Fernández-Larrea, J.; Pujadas, G.; Salvadó, J.; Arola, L.; Blay, M. Grape-seed procyanidins prevent low-grade inflammation by modulating cytokine expression in rats fed a high-fat diet. The Journal of Nutritional Biochemistry 2009, 20, 210-218, https://doi.org/10.1016/j.jnutbio.2008.02.005.

139.Liu, W.; Zhao, S.; Wang, J.; Shi, J.; Sun, Y.; Wang, W.; Ning, G.; Hong, J.; Liu, R. Grape seed proanthocyanidin extract ameliorates inflammation and adiposity by modulating gut microbiota in high-fat diet mice. Mol. Nutr. Food Res. 2017, 61, 1-33, https://doi.org/10.1002/mnfr.201601082.

140.Quiñones, M.; Guerrero, L.; Suarez, M.; Pons, Z.; Aleixandre, A.; Arola, L.; Muguerza, B. Low-molecular procyanidin rich grape seed extract exerts antihypertensive effect in males spontaneously hypertensive rats. Food Res. Int. 2013, 51, 587-595, https://doi.org/10.1016/j.foodres.2013.01.023.

141.Thiruchenduran, M.; Vijayan, N.A.; Sawaminathan, J.K.; Devaraj, S.N. Protective effect of grape seed proanthocyanidins against cholesterol cholic acid diet-induced hypercholesterolemia in rats. Cardiovasc. Pathol. 2011, 20, 361-368, https://doi.org/10.1016/j.carpath.2010.09.002.

142.Huang, L. ling; Pan, C.; Wang, L.; Ding, L.; Guo, K.; Wang, H. zhi; Xu, A. man; Gao, S. Protective effects of grape seed proanthocyanidins on cardiovascular remodeling in DOCA-salt hypertension rats. J. Nutr. Biochem. 2015, 26, 841-849, https://doi.org/10.1016/j.jnutbio.2015.03.007.

143.Pons, Z.; Guerrero, L.; Margalef, M.; Arola, L.; Arola-Arnal, A.; Muguerza, B. Effect of low molecular grape seed proanthocyanidins on blood pressure and lipid homeostasis in cafeteria diet-fed rats. J. Physiol. Biochem. 2014, 70, 629-637, https://doi.org/10.1007/s13105-014-0329-0.

144.Salvadó, M.J.; Casanova, E.; Fernández-Iglesias, A.; Arola, L.; Bladé, C. Roles of proanthocyanidin rich extracts in obesity. Food Funct. 2015, 6, 1053-1071, https://doi.org/10.1039/c4fo01035c.

145.Smeriglio, A.; Barreca, D.; Bellocco, E.; Trombetta, D. Proanthocyanidins and hydrolysable tannins: occurrence, dietary intake and pharmacological effects. Br. J. Pharmacol. 2017, 174, 1244-1262, https://doi.org/10.1111/bph.13630.

146. Steinmann, J.; Buer, J.; Pietschmann, T.; Steinmann, E. Anti-infective properties of epigallocatechin-3-gallate (EGCG), a component of green tea. Br. J. Pharmacol. 2013, 168, 1059-1073, https://doi.org/10.1111/bph.12009. 
147.Zeng, Y.X.; Wang, S.; Wei, L.; Cui, Y.Y.; Chen, Y.H. Proanthocyanidins: Components, Pharmacokinetics and Biomedical Properties. Am. J. Chin. Med. 2020, 48, 813-869, https://doi.org/10.1142/S0192415X2050041X.

148. Chibueze, I.P.; Earnest, E.O.; Sonne, M.I.; Emeka, I.E.; Daniel, A.L.; Basden, O.F. Antidiarrheal property of Napoleona imperialis may be due to procyanidins and ellagic acid derivatives. J. Appl. Pharm. Sci. 2016, 6, 101-106, https://doi.org/10.7324/JAPS.2016.60317.

149.Zhang, L.L.; Zhang, L.F.; Xu, J.G. Chemical composition, antibacterial activity and action mechanism of different extracts from hawthorn (Crataegus pinnatifida Bge.). Sci. Rep. 2020, 10, 1-13, https://doi.org/10.1038/s41598-020-65802-7.

150.Amparo, T.R.; Rodrigues, I.V.; Seibert, J.B.; Almeida, T.C.; Cabral, V.A.R.; Vieira, P.M. de A.; Brandão, G.C.; de Oliveira, M.L.G.; da Silva, G.N.; Dos Santos, O.D.H.; Filho, S.A.V.; Teixeira, L.F.M.; de Souza, G.H.B. Antibacterial substances from leaves of Protium spruceanum (Burseraceae): In vitro and in silico evaluation. Brazilian J. Pharm. Sci. 2020, 56, https://doi.org/10.1590/S2175-97902020000118474.

151.Hessen, J. Root Extract and Proanthocyanidins on Oral Bacteria Viability. J. Oral Med. 2021, 5, 2021.

152.Ćurković-Perica, M.; Hrenović, J.; Kugler, N.; Goić-Barišić, I.; Tkalec, M. Antibacterial activity of Pinus pinaster bark extract and its components against multidrug-resistant clinical isolates of Acinetobacter baumannii. Croat. Chem. Acta 2015, 88, 133-137, https://doi.org/10.5562/cca2548.

153.Jekabsone, A.; Sile, I.; Cochis, A.; Makrecka-Kuka, M.; Laucaityte, G.; Makarova, E.; Rimondini, L.; Bernotiene, R.; Raudone, L.; Vedlugaite, E.; Baniene, R.; Smalinskiene, A.; Savickiene, N.; Dambrova, M. Investigation of Antibacterial and Antiinflammatory Activities of Proanthocyanidins from Pelargonium sidoides DC Root Extract. Nutrients 2019, 11, https://doi.org/10.3390/nu11112829.

154.Silvan, J.M.; Gutiérrez-Docio, A.; Moreno-Fernandez, S.; Alarcón-Cavero, T.; Prodanov, M.; MartinezRodriguez, A.J. Procyanidin-rich extract from grape seeds as a putative tool against helicobacter pylori. Foods 2020, 9, 1-17, https://doi.org/10.3390/foods9101370.

155.Baldé, A.M.; van Hoof, L.; Pieters, L.A.; Berghe, D.A.V.; Vlietinck, A.J. Plant antiviral agents. VII. Antiviral and antibacterial proanthocyanidins from the bark of Pavetta owariensis. Phyther. Res. 1990, 4, 182-188, https://doi.org/10.1002/ptr.2650040505.

156.Lee, J.W.; Kim, Y. Il; Im, C.N.; Kim, S.W.; Kim, S.J.; Min, S.; Joo, Y.H.; Yim, S.V.; Chung, N. Grape Seed Proanthocyanidin Inhibits Mucin Synthesis and Viral Replication by Suppression of AP-1 and NF- $\mathrm{B}$ via p38 MAPKs/JNK Signaling Pathways in Respiratory Syncytial Virus-Infected A549 Cells. J. Agric. Food Chem. 2017, 65, 4472-4483, https://doi.org/10.1021/acs.jafc.7b00923.

157.Yang, Z.F.; Bai, L.P.; Huang, W.B.; Li, X.Z.; Zhao, S.S.; Zhong, N.S.; Jiang, Z.H. Comparison of in vitro antiviral activity of tea polyphenols against influenza $\mathrm{A}$ and $\mathrm{B}$ viruses and structure-activity relationship analysis. Fitoterapia 2014, 93, 47-53, https://doi.org/10.1016/j.fitote.2013.12.011.

158. Calland, N.; Albecka, A.; Belouzard, S.; Wychowski, C.; Duverlie, G.; Descamps, V.; Hober, D.; Dubuisson, J.; Rouillé, Y.; Séron, K. (-)-Epigallocatechin-3-gallate is a new inhibitor of hepatitis C virus entry. Hepatology 2012, 55, 720-729, https://doi.org/10.1002/hep.24803.

159.Wang, Y.Z.; Li, J.L.; Wang, X.; Zhang, T.; Ho, W.Z. (-)-Epigallocatechin-3-gallate enhances poly I:Cinduced interferon- $\lambda 1$ production and inhibits hepatitis $\mathrm{C}$ virus replication in hepatocytes. World J. Gastroenterol. 2017, 23, 5895-5903, https://doi.org/10.3748/wjg.v23.i32.5895.

160.Williamson, M.P.; McCormick, T.G.; Nance, C.L.; Shearer, W.T. Epigallocatechin gallate, the main polyphenol in green tea, binds to the T-cell receptor, CD4: Potential for HIV-1 therapy. J. Allergy Clin. Immunol. 2006, 118, 1369-1374, https://doi.org/10.1016/j.jaci.2006.08.016.

161. Yamaguchi, K.; Honda, M.; Ikigai, H.; Hara, Y.; Shimamura, T. Inhibitory effects of (-)-epigallocatechin gallate on the life cycle of human immunodeficiency virus type 1 (HIV-1). Antiviral Res. 2002, 53, 19-34, https://doi.org/10.1016/S0166-3542(01)00189-9.

162.Maroli, N.; Bhasuran, B.; Natarajan, J.; Kolandaivel, P. The potential role of procyanidin as a therapeutic agent against SARS-CoV-2: a text mining, molecular docking and molecular dynamics simulation approach. J. Biomol. Struct. Dyn. 2020, 1-16, https://doi.org/10.1080/07391102.2020.1823887.

163.Wang, Y.; Fang, S.; Wu, Y.; Cheng, X.; Zhang, L.-K.; Shen, X.-R.; Li, S.-Q.; Xu, J.-R.; Shang, W.-J.; Gao, Z.-B.; Xia, B.-Q. Discovery of SARS-CoV-2-E channel inhibitors as antiviral candidates. Acta Pharmacologica Sinica 2021, https://doi.org/10.1038/s41401-021-00732-2.

164.Zhu, Y.; Xie, D.Y. Docking Characterization and in vitro Inhibitory Activity of Flavan-3-ols and Dimeric Proanthocyanidins Against the Main Protease Activity of SARS-Cov-2. Front. Plant Sci. 2020, 11, 1-14, https://doi.org/10.3389/fpls.2020.601316.

165.Joshi, S.S.; Howell, A.B.; D’Souza, D.H. Antiviral effects of blueberry proanthocyanidins against Aichi virus. Food Microbiol. 2019, 82, 202-208, https://doi.org/10.1016/j.fm.2019.02.001.

166.Zhuang, M.; Jiang, H.; Suzuki, Y.; Li, X.; Xiao, P.; Tanaka, T.; Ling, H.; Yang, B.; Saitoh, H.; Zhang, L.; Qin, C.; Sugamura, K.; Hattori, T. Procyanidins and butanol extract of Cinnamomi Cortex inhibit SARS-CoV infection. Antiviral Research 2009, 82, 73-81, https://doi.org/10.1016/j.antiviral.2009.02.001.

167.Derksen, A.; Hensel, A.; Hafezi, W.; Herrmann, F.; Schmidt, T.J.; Ehrhardt, C.; Ludwig, S.; Kühn, J. 3-Ogalloylated procyanidins from Rumex acetosa L. inhibit the attachment of influenza A virus. PLoS One 2014, 9, https://doi.org/10.1371/journal.pone.0110089. 
168. Su, X.; Howell, A.B.; D’Souza, D.H. Antiviral effects of cranberry juice and cranberry proanthocyanidins on foodborne viral surrogates-A time dependence study in vitro. Food Microbiol. 2010, 27, 985-991, https://doi.org/10.1016/j.fm.2010.05.027. 